\title{
Global Law Schools on U.S. Models: Emerging Models of Consensus-Based Internationalization or Markets-Based Americanization Models of Global Legal Education
}

\author{
Larry Catá Backer ${ }^{1}$ \\ W. Richard and Mary Eshelman Faculty Scholar. Professor of Law and of International Affairs. \\ Pennsylvania State University. United States of America. \\ E-mail: Icb911@mac.com \\ Bret Stancil $^{2}$ \\ University of Pennsylvania (J.D. expected 2013). \\ E-mail: BStancil@law.upenn.edu
}

\section{Resumen}

En este artículo se examina dos enfoques sustancialmente incompatibles de la internacionalización que están surgiendo en los Estados Unidos. La primera se centra en la globalización del currículo escolar a través de la ley de internacionalización. Este enfoque es congruente con las nuevas tendencias en la internacionalización de la educación legal en Europa. La internacionalización de los enfoques en segundo lugar como la competencia por el mercado por la influencia entre dominante ordenamientos jurídicos nacionales, es decir, la globalización nacionalista. La internacionalización es entendida como la extensión de la influencia de la legislación nacional fuera del territorio nacional y está muy bien ilustrado por los recientes esfuerzos para globalizar el currículum escolar la ley por la internacionalización del derecho convencional EE.UU. currículo escolar. La tesis de principio es el siguiente: La comunidad global de educación legal, liderado por los europeos, ha sido la construcción de una visión de la globalización de la educación jurídica, que tiene como base la idea de la armonización y convergencia de los diferentes sistemas y el desarrollo de un nuevo modelo institucional basado en la armonización de las tendencias mundiales de la ley. Los Estados Unidos parecen

\footnotetext{
${ }^{1}$ An earlier version of this article was presented at Congreso sobre la internacionalización de la educación superior de derecho, Toledo, Spain, June 15, 2011. My thanks to the conference organizers, D. Pedro José Carrasco Parrilla, profesor titular and decano of the faculty of juridical and social sciences at the Universidad de Castilla-La Mancha and Dra. Eva Andrés Aucejo profesora titular at the Universitat de Barcelona.

${ }^{2}$ Many thanks to Professor Backer for both the experience to participate in the writing of this article and for his invaluable mentorship and guidance.
} 
estar tomando dos enfoques para este desarrollo. Por un lado, algunas instituciones están participando en la internacionalización de la educación. Sin embargo, las instituciones estadounidenses también están trabajando en contra de esta tendencia general al plantear una forma de globalización que tiene como fundamento la idea de que la enseñanza del derecho nacional puede ser globalizada y el rechazo de la necesidad de crear y enseñar derecho más allá del derecho nacional. En lugar de la armonización y la globalización del derecho, los estadounidenses de un modelo basado en la competencia extraterritorial para la socialización de las leyes del ordenamiento jurídico interno de los estados dominantes.

\section{Palabras clave}

Internacionalización, nacionalismo, globalización del currículo de derecho, enfoques pedagógicos, maestría en derecho, acreditación de estudios de derecho al extranjero, licenciatura de abogados.

\section{Abstract}

This article examines two substantially irreconcilable approaches to internationalization that are emerging in the United States. The first focuses on globalizing the law school curriculum through internationalization. This approach is congruent with emerging trends in legal education internationalization in Europe. The second approaches internationalization as a market driven competition for influence among dominant domestic legal orders, that is, as nationalist globalization. Internationalization is understood as the extension of the influence of national law outside the national territory and is nicely illustrated by recent efforts to globalize the law school curriculum by internationalizing the conventional U.S. law school curriculum. The principle thesis is this: The global legal education community, led by the Europeans, has been constructing a vision of globalization of legal education that has as its basis the idea of harmonization and convergence of different systems and the development of a new institutional model grounded in harmonized global trends in law. The United States appears to be taking two approaches to this development. After an Introduction, Part II examines the internationalization efforts of U.S. law schools following one of five models: (1) integration; (2) segregation; (3) aggregation; (4) immersion; and (5) multi-disciplinary department models. This project seeks a newer framework for the construction of shared legal structures grounded in joint effort that is not dominated by the approaches off any one state. Part III then examines the ways in which American institutions are also working against this general trend by positing a form of nationalist globalization that has as its foundation the idea that national legal education can go global without globalizing the law taught. Nationalist globalization takes three forms: a focus on the training of lawyers for domestic service whose pedagogical methodologies can be exported, the extraterritorial extension of the U.S. law school system, and the management of post graduate degrees in law for foreign law graduates. In place of harmonization and globalization of law, the American nationalist globalization model grounded in extraterritorial competition for socialization in the laws of 
the domestic legal order of dominant states. The article ends with an analysis of the consequences of these competing forms of global engagement in legal education. While much of the attention on changes to the American law school environment has focused on internationalization within consensus-based and supplementary programs founded on the internationalization ideal, American law schools have also been developing market-based strategies that are, at their core, fundamentally inconsistent with the internationalization framework.

\section{Key words}

Internationalization of law, legal nationalism, accreditation of law schools, LL.M. programs for foreign trained lawyers, legal education, licensing of lawyers, American Bar Association, dual degree programs. 


\section{PRESENTACIÓN:}

Hay una costumbre reciente de hablar de la libertad que nos trae las oportunidades a internacionalizar la educación y el derecho. Pero también nos trae una oportunidad de ejercer un poco el libertinaje. En este artículo intento hablar del libertinaje Americano en asuntos de la internacionalización. No hay un modelo sino varios modelos contrarios con efectos internacionalistas en desarrollo ahora en EEUU. ¿Desarrollos paralelos? La educación jurídica de EEUU esta afectada por dos fuerzas contrarias: por un lado, un Modelo Internacionalista: transnacional y énfasis más allá del estado. Fundado en el derecho internacional y comparativo, extranjero y transnacional en el currículo como parte de la formación jurídica básica de los estudiantes de derecho. Hay varios modelos utilizados. También se nota mucha variedad en la aplicación de estos modelos en los 200 facultades de derecho en EE.UU. Tendencias en la oposición se ajuntan en un Modelo Nacionalista, con énfasis en el derecho domestico; menos énfasis a lo más allá del estado. Informe de la Fundación Carnegie, Educating Lawyers: Preparation for the Profession of Law. Este último modelo tiene un mayor apoyo por ABA y los jueces, no tanto por las escuelas de derecho de élite. Han desarrollados distintas filosofías de implementación, pero todos con similares objetivos. Estos dos grandes esfuerzos de reforma de los últimos 20 años se han desarrollado a lo largo de vías paralelas de forma casi completamente aislados uno del otro. Analizamos el desarrollo de estos debates paralelos de la reforma de la educación legal de los EE.UU. Y del debate entre los dos sistemas distintos de "internacionalización".

Examinamos primero los métodos analíticos (métodos de evaluación). (2) Con esta base analítica, desagregamos CINCO modelos o métodos del internacionalismo; (1) Método de integración; (2) Método de agregación; (3) Método de segregación; (4) Método de Inmersión; y (5) Método de Creación de una facultad Multidisciplinario. Segundo, examinamos el Modelo Nacionalista. Discutiremos este modelo con énfasis a lo domestico y a los deseos de las colectivas judiciales y de abogados locales. Examinemos también la internacionalización del sistema y pedagogía Americana a través del extra-territorialismo ABA considera acreditación de facultades de derecho situado afuera del territorio nacional.

Respeto al Modelo Internacionalista, el análisis requiere una sistematización de enfoques analíticos, incluidos los siguientes: identificar los interesados (stakeholders); identificar los objetivos del programa (derecho comparativo, internacional, extranjero o transnacional y con qué fin); efectuar preferencias internas de la institución; utilizar los talentos y habilidades de los profesores; utilizar consenso; utilizar los recursos disponibles; expectativas realistas. Estos enfoques analíticos describen un proceso impulsado por intereses de varios grupos interesados: incluso, la administración, alumnos, empresarios, gobierno, tribunales y los clientes. Las necesidades y actitudes de cada uno y su poder relativo darán forma a la internacionalización. El resultado es significativo: la estratificación basada en las preferencias, incentivos, beneficios para miembros de la facultad y recursos institucionales. Facultades de más alta reputación y los que están más cerca de las fronteras son más propensos a participar más plenamente. Facultades de nivel secundario pero con más recursos también más propensos para poner en práctica. 
Con estos procesos en mente se puede examinar los métodos internacionalistas. El primero, integración, se base en la reorientación del centro educativo y de investigaciones de la Facultad de Derecho de la nacional a las transnacionales en la mayor medida posible. El objetivo es producir generalidades que combinen lo nacional e internacional. Este método es complicado y costoso; requiere transformaciones culturales: puede exigir que todos los profesores cambien sus enfoque a la enseñanza y la investigación; cambios fundamentales en la metodología de la profesión.

El segundo método internacionalista, agregación, es el modelo más popular-preserva distinciones entre las disciplinas en que se divide la "ciencia" de derecho. En muchas variedades, las asignaturas internacionales y transnacionales están separadas, pero consideradas como una entre iguales de los programas de estudio, así como derecho laboral, de empresas o la legislación fiscal. Sus ventajas: aprovecha enfoques convencionales para la enseñanza del derecho, no requiere un cambio real de la cultura o pedagogía. Sus inconvenientes: refuerza marco convencional, con énfasis a las fuentes del estudio de derecho en las órdenes jurídicas nacionales. Normas de suplementación no de integración.

El tercer método internacionalista, segregación, por lo cual la Facultad de Derecho crea un aparato administrativo que sirve como base institucional por la cual que todos los programas internacionales y transnacionales pueden ser desarrollados, ofrecidos, evaluados e incorporados en la misión de investigación de la educación y de la Facultad de Derecho. Es un sistema para la institucionalización del método de agregación. Sus ventajas: evita los problemas de la integración sistemática y formación del profesorado a través de múltiples disciplinas; es más fácil agregar programas adicionales: certificados, formación profesional; y es más fácil de administrar. Sus inconvenientes: instituciones pueden evitar el tema cultural; dos facultades creadas en efecto. Es también más fácil de terminar o reducir el tamaño del programa, más fácil de utilizar profesores sin (pista internacional subordinada); y se convierte en un gueto y pierdes conexión entre profesores.

El cuarto método internacionalistas, inmersión, es un método emergente de redes de instituciones. La base es la idea de que derecho extranjero se aprende in situ, la internacionalización a través de asociaciones con las facultades de derecho extranjero. Los alumnos eligen el área de estudio (sistema nacional extranjero) que se centran en el marco de la educación internacional. Ventajas: no requiere entrenamiento de profesores por uso de profesores en su sitio nacional, concesión de licencias en jurisdicciones múltiples posibles. Inconvenientes: no hay incorporación real de los internacionales o extranjeras dentro de la Facultad de Derecho; el programa depende de la capacidad de cultivar y mantener redes, puede ser costoso y difícil de administrar.

El último método internacionalista-creación de un departamento multidisciplinario adentro de la facultad de derecho, es más complicado y el menos desarrollado. Tiene dos enfoques principales: primero, el auto contenido sino que se organiza como porosa unidad de la Facultad de Derecho; segundo, unidad autónoma con conexiones fuera de la escuela de leyes. Ambos requieren el establecimiento de un nuevo departamento que se distingue la forma de la escuela de derecho. Las cuestiones de la segregación y de la aculturación se evitan; sin embargo, la internacionalización es reconocida como 
algo aparte del corpus de estudios nacionales y del "derecho" como se entiende en común.

Cuando hablamos de los modelos nacionalistas, entramos en un mundo donde los sistemas jurídicos nacionales predominan. Los nacionalistas creen mucho en la globalización de sistemas nacionales (ahora universalizados); pero rechazan internacionalización. En los modelos nacionalistas, la atención se centra en el entrenamiento práctico que es la filosofía principal de estos métodos en todas sus variaciones. El foco: el entrenamiento para servir pueblos (y clientes) locales. Igualmente, se nota un énfasis en la jurisdicción local; procesos judiciales y legislación; si no se aplica directamente es de menos interés. También un énfasis en entrenamiento de aspectos técnicos y útiles; relaciones con jueces y organizaciones de abogados de la localidad; y menos énfasis en materias más teoréticos/académicos. Hay tres variantes importantes del modelo nacionalista: (1) entrenamiento práctico bajo normas substantivos de los EE.UU.; (2) programas de maestría en derecho para abogados licenciados en otros países; y (3) el establecimiento de facultades americanas en universidades en el extranjero acreditado por ministerios nacionales del EE.UU. El primero, el método de momento se elabora en el Informe Carnegie del 2010. Separe la formación de abogados de cultura universitaria. Este método afirma que la práctica es más importante que la teoría / política. Como consecuencia, tiene el efecto de segregar facultades de derecho; los recursos determinará la medida en que puede ser el modelo utilizado, sin afectar la orientación académica de las facultades de derecho moderno; las facultades más pobres serán orientado más a lo local y lo de la a la formación; las más ricas podrán cumplir sin cambiar su orientación internacionalista o la cultura de sus facultades. Los otros métodos nacionalistas se refieren a la extensión extraterritorial del sistema jurídico educativo de EE.UU. Esto apunta a distintas maneras de participar en el mercado mundial para estudiantes de derecho. Pero en lugar de ampliar estudios internacionales en facultades de derecho nacionales, busca expandir el modelo nacional en el extranjero. Dos partes del modelo: reducir la disponibilidad de las licencias a través de programas de post-graduado (EE.UU. LLMs); y fomentar el establecimiento de escuelas de derecho de EE.UU. en el extranjero. Esfuerzo actual: propuesta de la "American Bar Association" de acreditación de facultades de derecho en universidades al extranjero que operan como universidades americanas. Dos informes-esquema de las propuestas: American Bar Association, Report of the Special Committeeon International Issues, 2009 (LacyCommittee); y American Bar Association, Report of Special Committee on Foreign Law Schools Seeking Approval Under ABA Standards, July 19, 2010 (KaneCommittee). El comite propuso cuatro recomendaciones. En primer lugar, el proyecto de acreditación debería seguir adelante. En segundo lugar, las normas de acreditación real deben ser examinadas y revisadas para evitar los posibles obstáculos a este proyecto de expansión geográfica. En tercer lugar, una declaración de política debería ser elaborada para asegurar el lugar central de la ley estadounidense, el idioma (Inglés), un cuerpo docente formado principalmente por los beneficiarios de USJDs, y una pedagogía de América en estas escuelas acreditadas extranjeras. Por último, el Comité recomendó a la prueba de funcionamiento de una escuela modelo que podría proporcionar la plantiIla aceptable para esta forma de expansión. Las justificaciones son interesantes e informativos: ayudar a los tribunales supremos estatales en sus procesos de licenciatura; controlar los requisitos y la manera de aculturación necesaria para licenciar-se; hacer 
más difícil la posibilidad de poder calificar para examinarse por medios de programas de maestría en derecho ofrecido por muchos facultades de derecho en EE.UU.; la profundización de la influencia del derecho EE.UU. y su sistema de educación legal como referente global "para mejorar la formación de abogados a nivel mundial y contribuir a la economía moderna y de la abogacía internacional"; este modelo contribuiría "al proceso global de armonización legal;" por último, reduciendo los obstáculos a la creación de sucursales el extranjero permitiría que las escuelas americanas convertirse en operaciones multinacionales por reducir los obstáculos a la creación de sucursales universitarias en el extranjero.

El Modelo Acreditación como desafío del internacionalismo global sustitutos de competición entre estados por el dominio de las culturas jurídicas en lugar de la creación de un consenso transnacional. Crea incentivos para que "descreme" los estudiantes al servicio de la jurisdicción extranjera; la enseñanza del derecho atado con los ideales y culturas jurídicas americanas se filtra fuera del ámbito académico y se aplica en la práctica, a menudo cambiando o subvirtiendo la legislación nacional. Al mismo tiempo, la entrada de grandes números de abogados extranjeros en el sistema EE.UU. podría transformar la práctica del sistema nacional, haciéndolo más global y menos nacional. La acreditación se combina con más grandes dificultades en calificar para examinación con un posgrado (LLM) de programas EE.UU. Existe la propuesta de incorporar sistemas más difíciles de licenciatura con programas de pos grado en derecho, incluso certificación de esos programas. Al mismo tiempo limita la flexibilidad de esos programas. Pero, estados que se conforman hacen más fácil el uso de estos programas para licenciar estudiantes del extranjero.

Sin embargo, hay algo de oposición importante a la acreditación externa de las escuelas de derecho. Gran parte de esa oposición se basa en el temor de la pérdida de los estudiantes. Pero algunos de los oposiciones también cultural - abogados extranjeros afectará a la cultura jurídica en los Estados Unidos, y el modelo se acreditación cambio de poder a los abogados de la licencia de los estados al gobierno federal. Sin embargo, la acreditación a extranjeros se basa en décadas de antigüedad programas de ABA de exportación con sede en EE.UU. las normas legales a través de su iniciativa "rule of law". Pero que, a su vez, ha sido criticado por su potencial efecto neo-colonialista.

Conclusión: Hay una enorme cantidad de actividad y discusión en EE.UU. en temas de la internacionalización de programas de educación de derecho. Pero estas discusiones y movimientos mueven en direcciones incompatibles - Internacionalistas y Nacionalistas. Qué va a prevalecer y qué será el carácter del consenso se queda por ver. Pero las opciones que se escogen afectarán el carácter de la educación legal de los EE.UU. y la forma en que el derecho internacional y los programas mundiales se desarrollan tanto en los Estados Unidos y en el extranjero. 


\section{Global Law Schools on U.S. Models: Emerging Models of Consensus-Based Internationalization or Markets-Based Americanization Models of Global Legal Education}

\section{Larry Catá Backer}

W. Richard and Mary Eshelman Faculty Scholar. Professor of Law and of International Affairs. Pennsylvania State University. United States of America.

E-mail: Icb911@mac.com

Bret Stancil

University of Pennsylvania (J.D. expected 2013).

E-mail: BStancil@law.upenn.edu

\section{INTRODUCTION}

The internationalization of legal education continues to gain momentum. Once a hodgepodge of efforts--harmonization based efforts in Europe, comparative law efforts from the United States and Japan, and development based efforts from Asia, Africa and Latin America--the focus of efforts now have increasingly stressed an internationalization of both curricular efforts in home faculties, and institutional arrangements within a growing network of participating institutions. While there is much focus on the efforts of American institutions to participate (and perhaps to seek to dominate) the framing and implementation of these efforts, there are equally important developments outside the United States, some of which include participation by U.S. educational institutions. ${ }^{3}$

\footnotetext{
${ }^{3}$ See, e.g., AishaLabi, As Universities Globalize, Consortia Take On a New Meaning, Chronicle of Higher Educaiton, Aug. 13, 2011.Available http://chronicle.com/article/As-UniversitiesGlobalize/128633/?sid=gn\&utm source=gn\&utm medium=en ("One network has taken the notion of collaboration a step farther, developing an entirely new institution with degree-granting authority of its own. The Euro-Mediterranean University, or Emuni, was created in 2008 following a Paris summit of 43 countries around the Mediterranean, including several in the Arab world. Involving nearly 200 member institutions, it provides what Joseph Mifsud, its president, calls "just-in-time education," focusing on pressing regional issues that are not adequately dealt with through traditional university syllabi and teaching methods").
} 
One approach seeks to transform legal education by blending legal studies from a variety of jurisdictions and creating a curriculum that starts as essentially transnational. Consider the Center for Transnational Legal Studies ${ }^{4}$ and its innovative structure, pedagogy and approach to legal internationalization. ${ }^{5}$ The Center for Transnational Legal Studies provides model for networked education, in which a number of law faculties from across the globe come together in a place not connected to any of them for the purpose of bringing selected numbers of each of their students and faculty together for instruction in a curriculum liberated from the structures of any of the domestic legal orders of any of the participating schools. ${ }^{6}$ It suggests a form of internationalization that is built through cooperative projects among a number of diverse institutions. But it has its complications--from cost to administration, to devoting the time and energy necessary to avoid deviating from the internationalizing mission of the program. Yet it evidences the possibility a useful pedagogy beyond the domestic legal order of any predominant state. There is now enough law beyond the state, and which affects actors in transactions across borders, to support a course of study and serve as a basis for training useful to lawyers. Yet this is not an endeavor for the fainthearted, or for institutions with inadequate resources to support such efforts.

Another approach emphasizes dual or multiple degrees. One, "El programa de dobletitulación de la Universidad de Barcelona con la Nova Southeastern University" provides a model of the form The presentation provided an analysis and description of emerging double degree programs, in this case leading to the possibility of acquiring law degrees (and consequently providing the necessary basis for seeking licensing as a lawyer) in multiple national jurisdictions. Professor Navarro suggested both the complexity and value of double degree programs. Beyond issues of coordination, the principle difficulty is one of language and students' sense of the existence of value in a double degree. Yet it also provides a mechanism for making it easier for students to take advantage of market opportunities across borders. When done correctly, it can also serve as a bridge for faculty interaction, exchange and research possibilities. That

\footnotetext{
${ }^{4}$ The Center's presence on the internet may be accessed at http://ctls.georgetown.edu/. "The Londonbased Center for Transnational Legal Studies (CTLS), a global partnership spearheaded by Georgetown University Law Center, will receive the 2011 Andrew Heiskell Award for International Partnerships from the Institute of International Education (IIE) on March 18 in New York. This is the first time the award has been given to a program focused on legal education." Georgetown Law School, Press Release, Center for Transnational Legal Studies Receives Award, Jan. 27, 2011; available http://www.law.georgetown.edu/news/releases/january.25.2011.html.

${ }^{5}$ Discussed in ArjonaSebastià "Transnational Law as an Excuse. How Teaching Law Without the State Makes Legal Education Better", in C. Menkel-Meadow \& F. Werro (eds.), Teaching Transnational Law,Ashgate (forthcoming, 2011).

6 "The London-based Center for Transnational Legal Studies, launched in 2008 and administered by Georgetown University Law Center staff, is a global partnership currently encompassing 24 schools from almost as many countries around the world. The initiative is premised on a belief that, as legal practice becomes increasingly "transnational", the best legal education must include exposure to ideas, faculty, and fellow students from many different legal systems." Centre for Transnational Legal Studies London, Brochure

(2011), available http://www.google.com/url?sa=t\&source=web\&cd=2\&ved=0CCAQFjAB\&url=http\%3A\%2F\%2Fctls.georg etown.edu\%2Fdocuments\%2FCTLS-

LondonBrochurePT.pdf\&rct=j\&q=georgetwon\%20center\%20for\%20translational\%20legal\%20studies\&ei=ctM1To6NAn00gGFufTwDw\&usg=AFQjCNENfxUZONjAeOPSxNzkvbuiVhQofg\&cad=rja
} 
bridge can also be used to bring faculty from the home to host state. The programs at the University of Navarra provide a case in point. ${ }^{7}$

Lastly, internationalization can be detached from a physical presence in any place. Some efforts now suggestthe possibilities of distance education in the context of the internationalization of legal education. What made the presentation particularly interesting were both the language of instruction and the growth of the market for this type of education delivery. Professor Gómez Jena noted that English had become the lingua franca of supra national legal studies--so that distance learning courses offered by this Spanish university abroad tended to be offered to non-Spanish audiences in English. He also described the substantial growth in interest in distance education. The distance learning efforts now reaches 160,000 students, and covers 26 field options, with a staff of about 10,000 instructors. The UNED option offers the possibility of internationalization without the cost associated with on-the-ground programs that may be limited to only the most well endowed institutions. It is likely that internationalization will at least be supplemented, if not spearheaded, through the use of technology, especially for those financially unable to create live programs.

This article examines two substantially irreconcilable approaches to internationalization that are emerging in the United States. The first focuses on globalizing the law school curriculum through internationalization. This approach is congruent with emerging trends in legal education internationalization in Europe. ${ }^{8}$ This Internationalist Model is transnational and outward looking. It focuses on modifying the traditional curricula by adding substantial international, comparative, foreign and transnational law elements into instruction and as a part of basic legal training of law students. U.S. law schools have internationalized their curricula following one of five models: (1) integration; (2) segregation; (3) aggregation; (4) immersion; and (5) multi-disciplinary department models. ${ }^{9}$ Internationalization, however, has been uneven, with a wide variation in the appetite of law schools for internationalization. Many schools, sensitive to the needs of the markets into which their students are likely to obtain employment, have opted for regionalization, localization or nationalization of their curricula. ${ }^{10}$

\footnotetext{
${ }^{7}$ NicolásZambranaTévar, La globalización de lasFacultades de Derecho: el Global Law Program de la Universidad de Navarra [Universidad de Navarra], paper presented at theCongresoSobra la internacionalización de la educación superior de derecho, Toledo, Spain, June 15, 2011.

${ }^{8}$ See, e.g., Joana AbrisketaUriarte y Cristina ChurrucaMuguruza, El MásterEuropeoConjunto en AcciónInternacionalHumanitaria: un másterbasado en competencias [Universidad de Deusto], paper presented at theCongresoSobra la internacionalización de la educación superior de derecho, Toledo, Spain, June 15, 2011; Manuel Bermejo Castrillo, y Pilar Otero González, Haciaunaformaciónjurídica sin fronteras. El reto de la implantación de titulacionesconjuntas de dimensióninternacional [Universidad Carlos III de Madrid],paper presented at theCongresoSobra la internacionalización de la educación superior de derecho, Toledo, Spain, June 15, 2011.

${ }^{9}$ Discussed below at Section II. See, Larry Catá Backer, "Internationalizing the American Law School Curriculum (in Light of the Carnegie Foundation's Report)," in The Internalization of Law and Legal Education 49-112 (Jan Klabbers and Mortimer Sellers, Dordrecht, The Netherlands: Springer Science + Business Media B.V., 2008) (2 lusGentium: Comparative Perspectives on Law and Justice (Mortimer Sellers series ed.).

${ }^{10} \mathrm{An}$ influential U.S. academic in matters of the cultural expectations of legal education in the U.S. described the general understanding this way:
} 
The second approaches internationalization as a market driven competition for influence among dominant domestic legal orders, that is, as nationalist globalization. This approach is domestic and inward looking in its construction, ${ }^{11}$ and aggressively outward looking in its quest to dominate markets for the provision of legal education. Internationalization is understood as the extension of the influence of national law outside the national territory. Nationalist globalization is nicely illustrated by recent efforts to globalize the law school curriculum by internationalizing the conventional U.S. law school curriculum. Like its internationalist counterpart, nationalist internationalization is not universally accepted within the U.S. academic community. Elite law schools appear to have rejected the concept as a sole basis for engaging globally; some lower tiered law schools fear it for the foreign competition insertion into nonterritorial markets may bring. But U.S. legal entrepreneurs, some of them with elite educational backgrounds, have been influential in generating interest in this approach.

These two great reform efforts of the last 20 years have developed along parallel tracks and in substantial isolation from each other. Yet both have become influential in the United States, and both may affect the way in which U.S. legal educational institutions engage in relationships with non-U.S. law faculties, students and indigenous legal cultures. The principle thesis of the article is this: The global legal education community, led by the Europeans, has been constructing a vision of globalization of legal education that has as its basis the idea of harmonization and convergence of different systems and the development of a new institutional model grounded in harmonized global trends in law. But U.S. educational institutions are divided between two approaches to the development of the framework for engagement with globalization. On the one hand, some U.S. educational institutions are focusing educational internationalization on the internationalization of the curricula offered to their students. Other American institutions working against this general trend by positing a form of globalization that has as its foundation the idea that national legal education can go global without globalizing the law taught. In place of harmonization and globalization of law, this nationalist version of internationalization is grounded in extraterritorial competition for socialization in the laws of the domestic legal order of dominant states.

The consequences for harmonization of educational practice, and especially for consensus about educational curricula, might be profound. More importantly, the choice

Students, academics, and law schools themselves often talk in terms of schools being "national" or "regional," though there doesn't seem to be an agreed-upon set of criteria at work in such discussions. The vast majority of ABA-approved law schools are "national," for example, in offering a curriculum that is not specific to the state jurisdiction in which the school is located, so in terms of course offerings, "national" is the norm. More interesting to prospective students, and more likely what is at stake when students wonder whether a school is "national," are the employment prospects of graduates. Genuinely "national" law schools draw prospective employers to campus from around the nation, not just from the immediate area in which the school is located; more "regional" law schools mainly draw employers to campus from the immediate region.

Brian Leiter, "National" and "Regional" Law Schools," Brian Leiter's Law School Reports, Feb. 6, 2006, available http://leiterlawschool.typepad.com/leiter/2006/02/national and re.html.

${ }^{11}$ See, e.g., Judith W. Wegner, "Reframing Legal Education's Wicked Problems," 61(4) Rutgers Law Review 867-1008 (2009). 
of model could have profound effects on the legal cultures of target states, and the course of internationalization. The legal education sector is now the site for a contest between internationalization as a collaborative effort and global competition among domestic law systems as the foundation system for global legal culture. The first mirrors emerging collaborative, stakeholder driven, forms of internationalization in which the governance framework is public in character meant to develop and implement a rough consensus among participants. Its object is harmonization and collaboration to increase the efficiency of systemic interaction. ${ }^{12}$ The second mirrors emerging global market behaviors in which law and legal education are understood as commodities competing for markets in a borderless world. Its object is not so much amalgamation and harmonization as it is the globalization of the domestic legal order of the system most successful at presenting a national framework for the handling of legal issues on the global stage. For smaller and less developed states, it also represents the projection of foreign national law, and foreign national legal cultures into their states and their legal systems. This can be viewed as a useful addition to national legal aspirations or potentially as neo-colonialist intrusions. ${ }^{13}$ As such, it represents not merely globalization, but a sort of legal colonization.

Part II focuses on the internationalist model as developed in American law schools. It first suggests the analytical framework within which internationalization is constructed in the U.S. It then considers the forms and character of U.S. internationalization efforts in its integrationist, aggregationist, segregationist, immersion and multi-disciplinary forms. Part III then turns to the forms of the nationalist model. After suggesting the analytical framework, this part of the article examines several of the practical expressions of nationalist globalization of legal education: focus on the training of lawyers for domestic service, and the extraterritorial extension of the U.S. law school system.The recent and influential Carnegie Report illustrates the first. ${ }^{14}$ The second is illustrated by the regulation of Master of Laws programs for foreign law students ${ }^{15}$ and, more importantly, by the accreditation of foreign law schools with the effect of preparing foreign students for licensing and practice in any U.S. state. ${ }^{16}$ The article ends with an analysis of the consequences of these competing forms of global engagement in legal education.

\footnotetext{
12 Larry CatáBackerInter-Systemic Harmonization and Its Challenges for the Legal-State, in The Law of the Future and the Future of Law (HiiL Law of the Future Series, The Law of the Future and the Future of Law, Sam Muller, Stavros Zouridis, Laura Kistemaker and MorlyFrishman, eds., The Hague, Netherlands: TorkelOpsahi Academic Editor, 2011).

${ }^{13}$ See, e.g., theessays in TheExport of Legal Education (Ronald A. Brand and D. Wes Rist, eds.,Fanham (Surry, UK): Ashgate 2009).

${ }^{14}$ William M. Sullivan, Anne Colby, Judith Welch Wegner, Lloyd Bond, Lee S. Shulman, Educating Lawyers: Preparation for the Profession of Law (Carnegie Foundation; San Francisco: Jossy-Bass, 2007).

15 "The ABA sounds off on foreign-trained attorneys," The Posse List, May 24, 2011, available http://www.theposselist.com/2011/05/24/the-aba-sounds-off-on-foreign-trained-attorneys/ ("Sitting for the bar exam may soon be trickier for the thousands of foreign-trained attorneys who take the test each year. The New York Court of Appeals in April adopted stricter requirements for master of laws (LL.M.) programs, which help foreign lawyers gain eligibility to take the bar. The new rules focus primarily on the content of LL.M. programs, which many foreign attorneys use as an entry point into the domestic legal market.").

${ }^{16}$ See, e.g., Honorable Elizabeth B. Lacy, Report of the Special Comm. on International Issues, 2009 A.B.A. Sec. of Legal Educ. and Admissions to the Bar (Lacy Report) http://www.abajournal.com/files/FINAL.pdf.
} 


\section{INTERNATIONALIST MODELS. ${ }^{17}$}

Today, law schools that embraced the national law model face a challenge similar to that confronted a century ago. ${ }^{18}$ But instead of confronting the challenge of a "national" practice, legal education now confronts the realities of multi-jurisdictional practice, sometimes described as the internationalization of law and legal practice, with little more than a heavily traditional set of approaches to teaching and scholarship. ${ }^{19}$ Legal practice, traditionally grounded in the laws of states from which American lawyers are licensed, and substantially overlain with national rule systems affecting virtually every aspect of legal relations in the United States, now increasingly includes activities dependent of the application of rule or norm systems beyond that of the state or nation. $^{20}$

The movement to incorporate international and transnational multi-jurisdictional law within the law school curriculum has acquired its own dynamic. This section first briefly considers this incorporation movement on its own terms, focusing on the framework within which internationalization is implemented and incentives created to move toward curricular internationalization. Examination then turns to the traditional framework structures for incorporating the international and transnational element in law school curricula, research and service. These include an integration, segregation and aggregation model of incorporation. The section ends with a consideration of emerging framework structures: an immersion model for incorporating the international and transnational element in law school curriculum, research and service.

Key to understanding the framework within which internationalization is approached in American legal education circles is educational mission. Law Schools, like most other institutions, are notoriously reticent about articulating mission in other than the most general terms. Mission statements are usually broad enough to accommodate virtually any form of legal education. This is not a criticism, but a reminder that the mission of law school is often apparent more from its practice than from its statements. The reality of mission, rather than its formal articulation, must be the basis for assessment. That, in turn, is a function of a variety of factors.

First, internal institutional preferences are important. The long-term preferences of stakeholders are a basic component of purpose. But, it is the most difficult component

\footnotetext{
${ }^{17}$ ThissectionisderivedsubstantiallyfromLarry Catá Backer, "Internationalizing the American Law School Curriculum (in Light of the Carnegie Foundation's Report)," supra, 8.

18 See Harold HongjuKoh, Luncheon Address (May 17, 2006), in American Law Institute Remarks and Addresses $83^{\text {rd }}$ Annual Meeting, Washington, D.C. pp. 65-89.

${ }^{19}$ Academics have noted the coming of this reality for a number of years. See, e.g., Louis F. Del Duca\& Vanessa P. Sciarra, Developing Cross-Border Practice Rules: Challenges and Opportunities for Legal Education, 21 FoRdHAM INT'L L.J. 1109 (1998); Roger J. Goebel, Professional Qualification and Educational Requirements for Law Practice in a Foreign Country: Bridging the Cultural Gap, 63 TUL. L. REV. 443, 447 (1989).

${ }^{20}$ Larry Catá Backer, "Internationalizing the American Law School Curriculum (in Light of the Carnegie Foundation's Report)," supra, note 8.
} 
to fairly assess. Second, abilities of the faculty will necessarily reduce options for incorporation. The aptitude of faculty, over the long term, and their willingness to conform to changes in the values of the production of certain kinds of knowledge, will substantially affect the ability of a law school to incorporate changes, including but not limited to the addition of the international and transnational element, to the curriculum and research. Third, without consensus a successful incorporation is unlikely. An institution led unwillingly to follow any course of action acts at its own peril. The hard work of consensus building, of building a desire to participate based on fair assessments of future realities, present capabilities, and resources, and the benefits of success (a success that must be fairly shared among institutional actors) is critical in any program of change. Where consensus goes missing, failure, however packaged and veiled, will surely follow. Fourth, available resources are critical. Change is not cost free. The allocation of resources directly impacts all faculty and law school programs. Resource allocation affects power relationships within a faculty. It also affects morale. A law school without the ability or will to commit the necessary resources to effect successfully the introduction of the transnational element into its teaching and research culture, will not be able to engage in the exercise. Fifth, realistic expectations define the parameters of successful incorporation. The realities of the hierarchies of the legal academy, and the rigorously enforced behavioral expectations that flow from that hierarchy are not lightly bucked. Dreams sometimes may not be realized. A realistic self assessment of the possibilities permitted a law school given its resources and place within the American academic reputation hierarchy is a necessary primary step in any consideration of moving to affect programs undertaken by reputation and resource leaders in the industry.

Capability provides the baseline for a number of decisions: the cost of embracing a program of international and transnational legal education, the form that program may or must take, the cost of amassing sufficient capability to make any such program viable, the likelihood of success for the program to be implemented, and the consequences (especially in terms of resource allocation) of embracing any such program. Capability issues reminds us that without physical and personnel resources, no amount of compelling theory can be turned to reality. It also suggests that uniform movement will be impossible; law schools will necessarily approach internationalization differently, in part, not because of ideological assessments but because of the realities of capabilities. As such, elite and well resourced law schools will likely choose methods of internationalization on the basis of criteria substantially different from those used by the least well reported or resourced law schools. .

Assessments of this type require the taking of an institutional inventory. ${ }^{21}$ This inventory assesses both personnel and facility capabilities. There also may be a gap between identification of the willing, and willingness to change old teaching and coverage ha-

\footnotetext{
${ }^{21}$ Such an inventory must take into account a number of things. Among the most important might be the following: (1) Current course coverage; (2) Potential course coverage given faculty ability and preferences; (3) Current programs in place; (4) Potential programs that might be implemented; (5) Necessary course coverage to meet the objectives of adding the international and transnational dimension in legal education; (6) Necessary programs to meet the objectives of adding the international and transnational dimension in legal education; (7) Necessary faculty additions to meet coverage, research and other programmatic needs; and (8) Necessary administrative support necessary to support the programs.
} 
bits. It is also not always easy to manage faculty education. ${ }^{22}$ It is also not easy to determine minima for course and program requirements. And those minima may be substantially affected by objectives - what is the precise nature of the product to be provided. ${ }^{23}$ Planning involves shooting at a moving target on multiple levels. That reality affects the resources that would be realistically necessary to commit to the program. It may thus affect the form that any program of naturalizing the international and transnational element within a particular law school may take.

Though the resulting form of participation in internationalization can take a large variety of forms, these can be reduced to five types. There are three traditional models for incorporating the international and transnational element into law school curricula: the integration, aggregation and segregation models. Each seeks to modify existing resources and teaching/research models to incorporate a transnational element into the curriculum.

1. Integration model. The first is the most comprehensive and "deep" form of integration, one that parallels the integration of "national" law in law school curricula, research and service at the start of the $20^{\text {th }}$ century. This is an approach being attempted by a few institutions, most of which consider themselves (or might be considered by others) at the higher reputation levels of the legal academy. It is marked, at least in theory, by an attempt to refocus the educational and research hub of the law school from the national to the transnational to the greatest extent feasible. The object is to produce generalists. ${ }^{24}$

\footnotetext{
${ }^{22}$ Thus, for example, this may affect matters like post tenure review processes, faculty support levels, teaching loads and the like. Essentially, incorporation in any of its aspects might change the set of fundamental contract and network relationships on which the field of legal production at the law school level has been organized for nearly a century. Those changes, to the extent they are fundamental enough, could require a great deal of attention, time and money. They will certainly pose significant institutional issues to the extent that its effects and obligations are meant to be spread widely among the faculty, or otherwise draw substantial resources away from traditionally privileged areas of funding.

${ }^{23}$ This question involves both a consideration of the relationship between program content and student (what does one want the students to get out of the program), program content and faculty (what does one want to suggest about the relationship of law faculty to the fields of law to which they are devoting their professional careers), and program content to outside stakeholders - the bench and bar, prospective students, alumni, the local community and community of global peers (how does one want to brand the efforts). Branding is a particularly sensitive issue and one that affects both the internal and external relations of law schools as institutions within the hierarchy of institutions in the field. Thus, for example, branding within a field not recognized by rating groups (e.g. U.S. News \& World Report (U.S. News \& World Report, Guide to Law Schools, Rankings, available at http://gradschools.usnews.rankingsandreviews.com/usnews/edu/grad/rankings/law/lawindex brief.php (accessed Aug. 27, 2007)) or even the Leiter Reports (see Brian Leiter's Law School Reports, available http://leiterlawschool.typepad.com/ (accessed Sept. 1, 2007)) may yield costs in excess of institutional advantages. The lack of institutional advantages invariably translates, in some respects, to the individual. For example, the U.S. News and World Report Rankings rank specialties in (1) clinical training, (2) dispute resolution, (3) environmental law, (4) healthcare law, (5) intellectual property law, (6) international law, (7) legal writing, (8) tax law, and (9) trial advocacy (id., at http://gradschools.usnews.rankingsandreviews.com/usnews/edu/grad/rankings/law/lawindex brief.php (accessed Aug. 29, 2007) but not in other fields.

${ }^{24}$ See, e.g., SebastienLebel-Grenier, What is a Transnational Legal Education, 56J. LEG. Educ. 190, 195-96 (2006).
} 
This more or less comprehensive approach is complicated and requires a large institutional commitment in terms of resources and a willingness to change traditional academic culture. ${ }^{25}$ At its limit, this approach requires all faculty to change their approach to teaching and perhaps even to research. Just as the focus of research at elite institutions shifted from state to national issues and from technical to theoretical discourse, the focus of research under this new approach may require a shift from the national to the cross or multi-jurisdictional.

2. Aggregation Model. The second, and most popular, model of integration, is based on the "field of law" or aggregation model, by which international and transnational issues are segregated and privileged as one among equals of areas of study of lawlike labor, corporate or tax law. The strength of this approach lies in its ability to leverage conventional approaches to law teaching. The great danger of this approach is that it will reinforce the conventional framework that privileges a strictly delimited territorial approach to legal education.

Under this model, international and transnational law (however understood) is consolidated in a number of courses, the extent and number of which will vary with the tastes of a faculty, their resources, capacities and the perceived interests of their local markets. This method involves virtually no changes to the structure of a law school's programs. It reduces the issue to one of resource allocation. A number of courses are identified. These courses are developed and faculty found to teach them. Perhaps additional programs, ad hoc or more institutionalized in nature, are established, and students are encouraged to take advantage of the "value added" of such programs in the same way they would be encouraged to take advantage of other institutional resources that might be good for them.

At its most imposing, this method permits a law school to provide a structure for the study of law as it relates to jurisdictions outside the United States. At its least imposing, this approach is informal, easily integrated with other similar programs, and reduces any possibility of privileging the international and transnational element of law. These sorts of aggregation or add on programs can easily do more to further the appearance of movement to an incorporation of a lively international and transnational component to legal education than to actually incorporate such instruction in fact. It can suggest that transnational law neither presents systemic issues of education nor approaches to law and legal practice, nor does it require a change in the way law is understood. It is an add on course. It diverts resources but otherwise effects no fundamental change in the way the business of legal education is conducted. For many

\footnotetext{
25 I noted in earlier work that "[t]here exist several significant impediments to any movement in this direction. The addition of international and comparative themes to existing courses, and especially existing first year courses, may present fatal obstacles." Larry Catá Backer, Human Rights and Legal Education in the Western Hemisphere: Legal Parochialism and Hollow Universalism, 21 PENN STATE INTERNATIONAL LAW REVIEW 115, 151 (2002).
} 
schools, especially those who do not expect many students to be affected, at least in the short term, by the turn to cross border practice, this may be enough. ${ }^{26}$

3. Segregation Model. The third model is the segregation model. There are two basic approaches under this model. The first is to migrate all internationalization effortspedagogical and research oriented-into a center within the law school, usually under the direction of a faculty member. These suggest small aggregate efforts. The second is more ambitious. Under this approach, a law school creates an administrative device that serves as the institutional base from which all international and transnational programs can be developed, offered, assessed and participate in the education and research mission of the law school. This method is powerful. It can avoid the issue of systemic integration and the training of faculty across disciplines. It respects more or less traditional disciplinary boundaries within the conventional law school. It can provide an easy way to monitor resource allocation and the performance of the programs, now gathered together within a single subunit. It can also be combined with certificate or other specialized programs in legal education offered to willing law students.On the other hand, such a model can serve as a gateway to greater integration.But the resources required for this sort of program may be beyond the reach of all but a few schools. On the other hand, the administrative separation of non-domestic law programs can keep this area apart from other law school educational functions. It segregates internationalization not merely at the student but also at the faculty level. For faculty and students who have no interest in internationalization, the centers make it possible to continue to operate as if they did not exist.

Two emerging framework structures stand out among the less traditional approaches to the incorporation of transnational elements in legal education. The first, the immersion model, applies the lessons of economic globalization to the business of legal education.The second, the multi-disciplinary departmental model, is based on the idea that the transnational element in law is distinct enough to merit a substantial treatment in its own right. Grounded in the traditional segregation model, it extracts all international and transnational legal studies-teaching and research-from the undifferentiated law school curriculum and places it within associated or affiliated departments of international law or international affairs that is not just a separate law department, but a focus of multi-disciplinary study built around the study of rule systems across borders.

1. Immersion Model. It is possible to construct from out of very recent developments, the skeleton of a possible alternative model that I might call the immersion model.The immersion model starts from the idea that law of other jurisdictions is best learned in those jurisdictions, with their students and in their language. It suggests that international and transnational law may require a sensitivity to context that makes collaborative efforts essential to understand all sides of any transaction involving the application of the law of multiple jurisdictions. As a consequence, a truly transnational program requires the participation of educational institutions in multiple jurisdictions. It accepts

\footnotetext{
${ }^{26}$ Many law schools still face the situation described in 1997 with respect to academic course inventory for legal education. See, e.g., John A. Barrett, Jr., International Legal Education in U.S. Law Schools: Plenty of Offerings but Too Few Students, 31INT'L LAW. 845 (1997).
} 
that beyond some level of generality, the transnational element of legal education must always be partial. Students must choose: language, system, and perspective. There can be no such thing, at a level of specificity necessary for practice, of the possibility of an acquisition of a generalist's knowledge. And the object of such education, in the most developed case, ought to be licensing in the multiple jurisdictions studied.In either case, the bulk of law school resources would not be used on 'retooling' or otherwise requiring faculty trained in the municipal law of the state in which they might be licensed to learn something else.That education would come in situ abroad, to the extent that it is otherwise not attainable within the domestic institution. The greatest expenditure would be focused on the cultivation and maintenance of webs of relationships with other institutions in other states. In addition, the barrier of language, especially for American law students, may become a great impediment to the growth of these programs beyond a small group of universities.

2. Multi-Disciplinary Departmental Model. Law schools have begun to consider the value of establishing schools or departments of international transactions or international affairs (a "DIA"). It is based on the development of a self-contained but porous unit of the law school devoted to a particular focus of law-related education, as a basis for the reconstruction of law school pedagogy. Alternatively the department could be kept free of direct law school faculty participation (or affiliation) and serve merely as an organizing focus for the interdisciplinary focus of teaching the international and transnational elements of law.

Such an approach would permit a law school not only to segregate international and transnational legal education within its institutional matrix, but also to use the segregation as a means of focusing on building bridges to related disciplines that would enrich any study of legal issues across borders. A DIA can also serve as a space within which all of the international and transnational energies of a law school can be focused. This approach is essentially the conceptual opposite of the immersion model. Instead of incorporating the transnational element within the curriculum and research/service of a substantial portion of the faculty, the multi-disciplinary department model starts with the assumption that the most efficient means of bringing the transnational element of law into law schools is to segregate the efforts. Once segregated, the transnational elements can be extracted and privileged within an environment in which it can be amplified by other related disciplines-international relations, politics, economics and business, for example. This extraction and recombination points to the great synergies possible with this approach, putting together lawyers and academics from related fields working together in an increasingly unified and powerful academic discipline (global law(s)) with many sub-disciplines (international law, international relations, comparative law, political theory, etc.). ${ }^{27}$ It provides efficiency and convenience, making international and transnational issues easy to place, maintain and resource.

\footnotetext{
${ }^{27}$ This model suggests the Canadian approach of teaching civil and common law within one faculty, but the division is along distinct functional lines. For a discussion of the approach at McGill, see Peter L. Strauss, Transsystemia-Are We Approaching a New Langdellian Moment? Is McGill Leading the Way? 56 J. LEG. EdUC. 161 (2006); Rosalie Jukier, Transnationalizing the Legal Curriculum: How to Teach What We Live, 56 J. LEG. EDUC. 172 (2006).
} 
On the other hand, there can be significant difficulties with this approach. For example, at its worst, it can serve as little more than a vehicle for empire building by deans and others eager to create something else to brag about without directly affecting the operation of the law school as such. Related to that is the issue of connectivity. Such a program runs a real risk of relating to law in name only-just another graduate department populating (in the ordinary course) large research universities. Unmoored to traditional programs, however, they might become either orphans (and ultimately abandoned) or become merged with international studies or other graduate departments where they might better belong. It also runs the risk of isolating faculty from its creation and operation. DIA programs can be effectuated outside of the law school environment. Law school faculty could have little to say about its structure, operations and most important, relationship to the law school itself. To the extent that DIA is operated independently of the law school (other than at the administrative level) DIA runs the risk of losing core law school support.

There are two substantially different methods of incorporating a DIA. The first is to affiliate a non-law DIA into the official structure of a law school as an autonomous department. Such a department would house the multi-disciplinary elements of transnational legal education.Alternatively, it might be possible to move (through joint or affiliation appointments) all law school faculty with primary international and transnational research or teaching interests to an affiliated DIA. They, along with non-law faculty, could together constitute an autonomous and internally complete department within the law school.The principal benefit would be to avoid disruption in the way law schools operate. Rather than force or induce change within a law school, a DIA model would serve as an addition (albeit an extremely significant one) to the body of the law school and its mission. It would change the fundamental orientation of a law school from strictly legal to effectively multi-disciplinary. ${ }^{28}$

Whatever their form, all of these approaches share certain common characteristics. First, they all assume an extension of the curriculum to areas of law and governance outside the traditional focus on the domestic legal order of the state. International and transnational law and governance extend or supplement national law. Internationalization suggests a consensus-based model in which national law system stakeholders collaborate in the creation and implementation of law and law cultures above the state. ${ }^{29}$ Second, they tend to assume that this extension is to law systems fundamentally distinct from the framing structure of domestic law. Internationalization is not merely a process of extending domestic law, but rather the addition of new and distinct forms of law. Third, internationalization also accepts as a general presumption that these international or transnational sources are not subordinate to or an appendage of domestic law. Rather, internationalization moves law from a vertically ordered conventional model grounded in the sovereignty of states with a monopoly of law power within their territories to a more horizontally ordered system in which law is the product of

\footnotetext{
${ }^{28}$ A detailed elaboration of the construction of a DIA is provided in Larry Catá Backer, "Internationalizing the American Law School Curriculum (in Light of the Carnegie Foundation's Report)," supra note 8.

${ }^{29}$ See, e.g., Edward McWhinneey, "Codifying International Law in an Era of Clashing Civilizations and Legal Cultures: The Sisyphaen Labors of the International Law Commission," in Law and Legal Culture in Comparative Perspective 222-244 (Guenther Doeker-Mach and Klaus A. Ziegert, ed., Munich \& Wiesbaden: Franz Steiner Verlag, 2004).
} 
consensus among states. In a sense, internationalization provides an opportunity to naturalize a very distinctive philosophy of law that can undermine the position of the state as the principal source of law. At its best, the object is to foster crossjurisdictional communication and learning to provide a multi-jurisdictional experience.

\section{Nationalist Models.}

While much of the attention on changes to the American law school environment has focused on internationalization within consensus-based and supplementary programs founded on the internationalization ideal, American law schools have also been developing market-based strategies that are, at their core, fundamentally inconsistent with the internationalization framework. These approaches, which this article subsumes under the name "nationalist globalization," share with the internationalization movement the presumption that law and governance has gone global. But unlike internationalization approaches that seek to expand the ambit of the law school curriculum by recognizing and including non-domestic law as an integral part of the law school curriculum, nationalist globalization movements seek to project the reach of domestic law, and the education in the domestic law and legal culture of the United States on a global scale. It represents recognition of the character of markets in legal education, and seeks to privilege the American participation by removing regulatory barriers to expansion of market share.

From a political perspective there is much to commend these approaches, at least from the policy perspective of maximizing American influence abroad using soft power. ${ }^{30}$ In an era when soft power is sometimes more effective than military intervention, dominating cultural markets and markets in legal ideology, methods and substantive law, substantially leverages American power. From an internal power dynamics perspective it also works to benefit the richest, most influential and powerful actors within legal academia. Not every law school has the resources to open branches or establish the sort of ties that might lead to U.S. accredited joint ventures with foreign law schools--and don't be surprised if many of these foreign ventures are not at least initiaIly structured as joint ventures between U.S. law schools and foreign academic units. The rules would tend to cement the privilege of the upper tier of American law school and deepen the divide between the haves and "have-nots" of a formally egalitarian but functionally class structured system of American legal education. Lastly the emphasis on English also produces a strong socio-cultural effect by deepening the power of English as the global language. Values are easier to transmit through a common language than in translation.

Yet some of these powerful incentives to move forward with this enterprise from the American perspective might provide a caution to those on the receiving end of the transaction. It is not too long a path from harmonization to subordination and from guidance to domination. These efforts can be as intrusive in host states as the erection of military bases--and more effective because they are meant to be open and inviting

\footnotetext{
${ }^{30}$ See Paul Harris, "Hawks Depart as Clinton ushers in new era of US 'soft power', The Guardian (UK), Jan. 11, 2009. Available http://www.guardian.co.uk/world/2009/jan/11/obama-white-house-clinton.
} 
rather than walled off and secured. On the other hand, the process suggests partnership. It is as likely that a great infusion of foreign voices into American programs will change Americans as it will acculturate the foreigners. American culture is particularly susceptible to foreign influence--but Americans tend to absorb foreign influences and naturalize them within its own culture rather than avoid them as threats, at least inthe long run.

This section considers three nationalist models of globalization of American legal education. The first are those grounded in the practical lawyering skills based movements that are exemplified by the recent work of the Carnegie Commission. These are programs that look inward and tend to ignore the importance of international or nonstate law in the curriculum. Yet, though these programs look inward, their pedagogies and the underlying cultural frameworks can be exported. The second and third comprise the most interesting development of approaches to nationalist globalization, that is to efforts to globalize American law as a response to internationalization trends. These have been managed through the American Bar Association, in its role in the management of accreditation standards for the practice of law in the United States, and principally through its Section of Legal Education and Admissions to the Bar. ${ }^{31}$ One focuses on consideration of the possibility of accrediting foreign law schools to teach U.S. law and to assimilate foreign lawyers into the American legal system. The other includes efforts to manage law school programs in post-graduate legal instruction designed to provide a means by which foreign lawyers may acquire a license to practice law in the United States (and principally in New York). This section ends with an analysis of these nationalist efforts to globalize legal education in terms of their character and effects within the United States and as they might affect the nature of the internationalization of legal education.

1. Inward Looking Approaches to Legal Education. This approach can be dealt with quickly. It reflects a conservative and inward looking trend in American legal education that recoils at the internationalist project, as well as the academic turn in legal education. It focuses its efforts on techniques designed to bring legal education back to a closer relationship to the local needs of domestic communities and the resident judicial establishment. It is grounded in professional training of the sort that used to be the burden of law firms until it became too economically burdensome for them and has found its most complete current expression in the work of the Carnegie Foundation for the Advancement of Teaching. ${ }^{32}$ For that purpose, Educating Lawyers proposes a unitary framework for education within which the doctrinal, practice and ethical elements of practice can be integrated ${ }^{33}$ within the normative context of a university environment in the form of a set of three related apprenticeships of professional education. ${ }^{34}$

\footnotetext{
${ }^{31}$ TheSection "provide[s] leadership and services to those involved in legal education and admissions to the bar. We serve, through our Council as the nationally recognized accrediting body for American legal education, providing a fair law school accrediting system that promotes quality legal education." American Bar Association, Section of Legal Education and Admissions to the Bar, About the Section. Available http://www.americanbar.org/groups/legal education.html.

${ }^{32}$ William M. Sullivan, Anne Colby, Judith Welch Wegner, Lloyd Bond, Lee S., Shulman, Educating Lawyers: Preparation for the Profession (San Francisco, CA: Jossey-Bass, 2007)

${ }^{33}$ Id. , at 194-197.

${ }^{34}$ Id., at $27-29$.
} 
For its effects on legal internationalization, perhaps, the greatest influence of these efforts is its emphasis on the cultural dimension of legal education, through what is referenced as methodology.

Methodology focuses on socialization. What law schools do well is teach doctrine. What law schools must do better is to teach the individual to "think like a lawyer." ${ }^{25}$ That involves more than the transmission of doctrine, even the transmission in a peculiar way. It involves the socialization of the individual into the mores and habits of a community, and in doing so more consciously take up the role once reserved to the bar and bound up in its transmission of the "craft, judgment, and public responsibility" ${ }^{36}$ of lawyers. That socialization focuses on the case dialogue method of instruction. ${ }^{37}$

It also touches on issues of professional identity and purpose. These efforts also seek to modify the framework within which academics speak about education. It is meant to remind the academy that legal education is not a closed autonomous system running exclusively on the basis of its own imperatives to feed the desires of the professorate (and increasingly more importantly of the bloating superstructure of administrators that purport to serve them and the institutions for which they work). ${ }^{38}$ More importantly, these efforts suggest a substantial predilection to marginalize the study of subjects not tied to the examining jurisdiction, or at least to segregating them.

But the techniques of these inward looking approaches themselves have been influential in shaping an international consensus about educational methodologies that have been important in internationalist models of legal education. ${ }^{39}$ The first element of integration focuses on the signature pedagogy highlighted in Educating Lawyers. ${ }^{40}$ The integration model is probably most suited. All of the incorporation models are heavily focused on doctrine. As to the pedagogy itself, it seems here that the limitations of the case dialogue method, so well discussed in Educating Lawyers, ${ }^{41}$ can be most powerfuIly felt. Though possible, it is not clear that the case dialogue method is most suitable for conveying the essence of European Union law, though its insights might to some extent translate. The second is a sensitivity to practice issues. ${ }^{42}$ On the one hand, the practice aspects of foreign and international law to which the United States does not subscribe present serious difficulties. Clearly, the immersion model might appear to be best suited to drawing out the practice aspects of non-domestic law; internships, discussions with local practitioners and the local bar, for example, all add a significant dimension to the usual doctrinal education that serves as the core of any pedagogical

\footnotetext{
${ }^{35}$ Id., at 47.

${ }^{36}$ Id., at 4.

${ }^{37}$ Larry CatáBacker, "Internationalizing the American Law School Curriculum (in Light of the Carnegie Foundation's Report)," supra, note 8.

${ }^{38}$ See essays in Gunther Teubner, ed., Autopoietic LaW: A NeW Approach To LAW ANd Society (Berlin: Walter de Gruyter\& Co Gunther, 1988).

${ }^{39}$ From Larry CatáBacker, "Internationalizing the American Law School Curriculum (in Light of the Carnegie Foundation's Report)," supra note 8.

${ }^{40}$ Educating Lawyers, supra note 15 , at $47-86$.

${ }^{41}$ See Educating Lawyers, supra note 15 at 75-78.

${ }^{42}$ Educating Lawyers, supra note 15 , at 87-125.
} 
program. The third is the values dimension of a legal education. ${ }^{43}$ On the one hand, international (that is non-domestic) courses ought to deepen the moral values instruction of American law for the construction of ethical lawyers - a great objective of Educating Lawyers. On the other hand, non-domestic law is as bound up as American law within the ethical and moral framework from which it arises. Yet, method can alter framework. ${ }^{44}$

Yet, it appears that not every method of internationalization provides a useful method for incorporating the integrative model advanced in Educating Lawyers. Among them, the integration model, ironically enough, is least likely to serve as a vehicle for incorporating the pedagogical framework of Educating Lawyers successfully. The aggregation model provides a compromise, but might lack enough resources to bring in ethics and practice elements. Though each likely requires substantially more resources, the segregation and immersion models may be better alternatives. In this respect the difficulties of incorporation parallel the problems of adopting the integrative model of Educating Lawyers within the domestic law curriculum. ${ }^{45}$

Moving the legal curriculum beyond the borders of the state is inevitable. So is the connection between legal education and the needs of the bench and bar. The two together might suggest an inward turning in the construction of pedagogy and then its outward exportation either as pedagogical methodology or as a bundling of universalizing substantive elements. But as we have seen, the development of methodological methodology might as easily be combined with an internationalizing substance for the construction of non-national substantive pedagogies.

\section{Extraterritorial Accreditation of U.S. Style Law Schools; The Americanization of} Global Legal Education. Recognizing that the legal profession is not immune to, nor unable to benefit from, the expansion of a global economy, the American Bar Association ( $A B A$ ) has participated in a number of efforts and initiatives to contribute to and participate in the globalization of the legal profession. ${ }^{46}$ In their 2006 Strategic Plan, the Section of Legal Education and Admissions to the Bar directed the Section's Council to "develop a plan to 'ensure participation in discussions relating to international trade in legal services and the appropriate role of the Section in the international arena'."47 Responding to this directive, Council Chair Randy Hertz developed and appointed the Special Committee on International Issues and charged the Committee with the examination and review of any and all international issues that may affect the Section. ${ }^{48}$ Chaired by the Honorable Elizabeth B. Lacy, the Committee has been tasked with considering several aspects of the globalization of the legal profession; this section will

\footnotetext{
${ }^{43}$ Educating Lawyers, supra note 15 , at 126-161.

${ }^{44}$ See, e.g., JelanaArsic, The Socratic Method, Clinical Legal Education, and Mediation: Serving the Promotion of Rule of Law in Serbia, in Ronald A. Brand and D. Wes Rist, eds., TheExport of Legal Educaiton (Fanham (Surry, UK): Ashgate 2009).

45 "However, as we have seen, there are major obstacles such a development will have to overcome. A trade-off between higher costs and greater educational effectiveness is one. Resistance to change in a largely successful and comfortable academic enterprise is another." Id.

${ }^{46}$ Honorable Elizabeth B. Lacy, Report of the Special Comm. on International Issues, 2009 A.B.A. Sec. of Legal Educ. and Admissions to the Bar (Lacy Report) http://www.abajournal.com/files/FINAL.pdf

${ }^{47}$ Id. at 3

${ }^{48}$ Id.
} 
focus on the Committee's consideration of ABA accreditation of foreign law schools as presented in the Committee's July 15, 2009 report and the follow up recommendations outlined in the 2010 Report of the Special Committee on Foreign Law Schools Seeking Approval under ABA Standards.

a. The 2009 Report of the Special Committee of International Issues ("Lacy Report"). The Lacy Committee's consideration of ABA accreditation of foreign law schools is grounded in an understanding that the ABA's Section of Legal Education and Admissions to the Bar serves an important role in assisting and protecting state supreme courts by "insuring that persons licensed to practice law have the requisite legal education, are fully conversant with the American rule of professional responsibility, and the substantive law governing the responsibilities of lawyers to clients, courts, and others, and meet all character and fitness standards. ${ }^{49}$

The Committee report first considered the economic value of opening licensing to foreign lawyers.The Report noted the economic importance of legal services as an export in international trade. ${ }^{50}$ The Committee also recognized that every U.S. jurisdiction had seen an increase in foreign-born population, the natural result of which, the Committee suggested,would produce an increase of the interaction of these citizens with their home states---interactionsthat often require the support of domestic and foreigneducated attorneys. ${ }^{51}$

The Committee report also expressed the view that the ABA's current policies regarding the practice of foreign-educated attorneys were underdeveloped and have left states to determine their own standards. ${ }^{52}$ Concluding that supreme courts and bar administrators would benefit from, and seem to invite, efforts by the Section to articulate clear standards and criteria by which to determine the eligibility of foreign-

\footnotetext{
${ }^{49} / d$. at 4 . As such, the Committee report first considers the current landscape, standards, and need not only for foreign-educated attorneys, but also for uniform standards regulating admission of those attorneys to the bar, and then presents possible initiatives that the ABA Section of Legal Education and Admissions to the Bar may consider to facilitate the inclusion of foreign-trained attorneys in the American legal system. Although the Committee considers both an expansion of accreditation activities as well as the development of a model rule for the admission of foreign attorneys, this report will focus on the Committee's recommendation to expand accreditation activities.

50 "In 2007 alone, the United States exported \$6.4 billion, and imported \$1.6 billion, in legal services" Lacy Report at 7 (citing U.S. Dep't of Commerce. Bureau of Econ. Analysis. Int'I Econ. Accounts, U.S. Int'| Services.: Cross-Border Trade 1986-2007, and Services Supplied Through Affiliates. See infra Table 7: Business, Professional, and Technical Services." Http://www.bea.gov/international/intlserv.htm (the Committee also notes that these statistics do not include GATS Mode 3 international trade of legal services)

${ }^{51}$ Id. at 8

${ }^{52}$ For example, the report notes that, although many states have promulgated their own rules, the ABA does not have a policy on Pro Hac Vice admission, the admission of foreign-educated lawyers to the bar, or policies concerning foreign in-house counsel. Id. Although the ABA Commission on MultiJurisdictional Practice has developed rules regarding foreign-educated lawyers ability to practice as foreign legal consultants and on a temporary "fly-in fly-out" basis, states have been slow to adopt these rules and have been left to determine eligibility for admission to the bar without the guidance of the ABA. Id. at 11.See Terry Table on State Implementation of MJP Recommendations \#8 and 9. As of 2009 eight states had changed their FLC rule following MJP recommendation \#8 and seven states had adopted a foreign lawyer temporary practice rule consistent with MJP recommendation \#9. http://www.abanet.org/cpr/mip/8 and 9 status Chart.pdf
} 
educated bar applicants, ${ }^{53}$ the Committee next explored the justifications and implications of an expansion of the ABA's accreditation activities.

The Committee started with a foundational rationalization: because "overwhelmingly in the United States," a J.D. degree from an ABA accredited law school "satisfies the educational prerequisite established to qualify an applicant to sit for the bar examination," expansion of accreditation activities may serve to assist supreme courts and provide the criteria by which states could ensure the quality of an applicant's substantive legal education and the applicant's understanding of U.S. ethical standards. ${ }^{54}$ The Committee then identified three types of programs to consider for accreditation-(1) Foreign Law Schools Located Outside the U.S., Not Sponsored by a U.S. Law School, Teaching Non-U.S. Students; (2) Foreign Law Schools Modeling Their Programs Under Current ABA Standards; and (3) LL.M Programs Offered by American Law Schools to Foreign Law Graduates. ${ }^{55}$ With respect to each, the Committee posed the question: "whether and what initial or additional course of study should be required of a graduate of a non-U.S. law school in order to provide reasonable assurance to the state supreme courts that the graduate is qualified to be considered for bar admission?"56

With respect to foreign law schools located outside the U.S., not sponsored by a U.S. law school, teaching non-U.S. students, the Committee determined that ABA accreditation would require the development of extensive standards to account for the variation in the system of law taught and the level of education required of applicants before entering various foreign law programs. Nonetheless, the Committee suggested that despite this variation, baseline standards that "need to be present in any program," so long as they're sufficiently demanding, should serve to eliminate the need to make distinctions based on the different types of programs. Such focus would include criteria such as the amount of common law taught, the duration of the program, and the qualifications of students in the program. However, in the end, the Committee concluded that accreditation for schoolsin this category should be rejected on the grounds that the number of foreign law schools, each with diverse and complex programs, made this option too impractical to implement.

\footnotetext{
${ }^{53}$ The Committee anchors its contention that the ABA's assistance is needed by asserting that the results of a recent seven question questionnaire circulated to state supreme courts demonstrates that applications for bar admission by foreign-educated applicants has increased by $268 \%$ during the first three years for which there is data. Id. at 11.See infra Appendix B:Summary of Statistics for Bar Examination Applicants Educated in Law Schools Outside of the U.S. http://ncbex.org/baradmissions/stats/(Prepared by Laurel Terry April 22, 2009). Moreover, thirty-one of the thirty-eight jurisdictions participating in the questionnaire stated that they were open to receiving information on foreign legal education generally, foreign bar admission rules (32 out of 38 jurisdictions), and information regarding foreign character and fitness requirements. Id. Supporting the results of the Committee's questionnaire, the Committee notes that in 2007, the Conference of Chief Justices passed a resolution explicitly urging the ABA's Section of Legal Education and Admissions to the Bar to "consider developing and implementing a program to certify the quality of the legal education offered by universities in other common law countries." Lacy Report at 12 (citing Conference of Chief Justices, Resolution 8 Regarding Accreditation of Legal Education in Common Law Countries by the ABA Section on Legal Education and Admission to the Bar (Feb. 2007), http://ccj.ncsc.dni.us/LegalEducationResolutions/resol8AccredLegalEduc CommonLawCountries.html.

${ }^{54}$ Lacy Report at 27, 28

${ }^{55}$ Thethirdcategorywasdiscussed in thepreceedingsection.

${ }^{56}$ Id. at 27
} 
Focusing on the second category, foreign law schools modeling their courses of instruction on current ABA standards, the Committee was more aggressive, and posited that the Section should "abandon any notion of territorial restrictions in accreditation" and suggested that any school that is able to meet the current ABA accreditation standards, regardless of its location or affiliation, or lack-there-of, with a U.S. law school, should be allowed to seek accreditation. The Committee stated that, "although meeting current standards may be difficult," ${ }^{17}$ foreign law schools seeking accreditation under this category ought to be welcome to apply.

On the basis of this analysis, the Committee suggested that the ABA Section of Legal Education and Admission to the Bar engage in an information gathering collaboration with existing ABA entities such as the International Law Section, the Business Law Section, and the ABA Task Force on International Trade in Legal Services. Further, the Committee recommended that the Section establish a permanent committee on international issues. Following the Lacy Report's recommendation, the Council of the Section of Legal Education and Admission to the Bar agreed to the appointment of a standing International Issues Committee. The International Issues Committee was charged with considering issues relating to the use of the LL.M degree as a qualifying credential for admission to the bar exam and whether "special bar-admissions consideration" should be given to graduates of foreign law schools located in common law countries that follow a graduate law school model similar to that of the U.S. without actual ABA accreditation of the foreign law school. The International Issues Committee has recently released its reports. ${ }^{58}$

\section{b. The Report Of Special Committee On Foreign Law Schools Seeking Approval} Under ABA Standards ("Kane Report"). On June 10, 2010, the Special Committee on Foreign Law Schools Seeking Approval Under ABA Standards was created to consider the policy implications and justifications of expanding accreditation activities to accredit foreign law schools modeling their programs on the U.S. model and seeking accreditation under the current ABA standards (as recommended by the Lacy report). Chaired by Mary Kay Kane, the Special Committee was asked to present its report at the Section of Legal Education and Admission to the Bar's August 2010 meeting. On July 19, 2010, the Special Committee released its report, the Kane Report, ${ }^{59}$ which focused onaccreditation policy, implementation issues if accreditation of foreign schools were to proceed, and concluded with recommendations for the future.

The Committee divided its Report into three parts. "The first discusses the policy implications and justifications for expanding the accreditation role of the ABA Section to encompass law schools located outside the United States or its territories. The second considers what special rules or concerns might need to be addressed should the Coun-

\footnotetext{
${ }^{57} I$. at 30 . Moreover, the Committee recommended that the Section consider exemption for these schools from certain current ABA standards that are exclusively applicable to the U.S., such as the requirement that law student's undergraduate institutions be accredited by an organization certified by the U.S. Department of Education.

${ }^{58}$ Discussedinfra.

${ }^{59}$ See Mary K. Kane, Report of Special Comm. on Foreign Law Schools Seeking Approval Under ABA Standards, 2009 A.B.A. Sec. of Legal Educ. and Admissions to the Bar (Kane Report). § II at 5, 6, 7.http://www.abajournal.com/files/kanereportinternational.pdf(Kane Committee Report).
} 
cil determine to proceed to consider applications coming from such law schools. FinaIly, the report concludes with a series of recommendations." ${ }^{60}$ The Committee made four recommendations. First, the accreditation project should go forward. Second, the actual accreditation standards should be reviewed and revised to avoid any barriers to this geographic expansion. Third, a policy statement ought to be drafted to ensure the central place in these foreign U.S. accredited schools of American law and pedagogy, the English language, and a faculty consisting primarily of U.S. J.D. recipient. Lastly, the Committee recommended conducting a trial run utilizing a model school in order to provide atemplate for this form of expansion. ${ }^{61}$

The Committee offered six justifications for an expansion of accreditation and three cautions against expansion. ${ }^{62}$ The justifications included aiding state supreme courts in their bar admissions functions, controlling the route to and the acculturation required for bar admissions, avoiding the shortcut to bar preparation for foreigners offered through the lucrative markets for LL.M. degrees, and deepening the influence of American law and American legal education as the gold standard for global legal education in an effort "to improve the training of lawyers globally and contribute to the modern economy and the international legal profession." ${ }^{63}$ In addition, the Committee advanced the notion that such programs of accreditation would aid in the process of global legal harmonization. That is, "[e]xpanding accreditation to schools outside U.S. borders that focus on U.S. law will allow these schools to be in a position potentially to develop cutting-edge curricula to address these trends and the Section thus will be in a position to be an active player in the dialogue about how to develop high quality legal training for the global economy." ${ }^{64}$ Lastly, it would permit American law schools to become multinational operations by reducing barriers to the establishment of branch campuses abroad. The cautions against expansion included reducing barriers to entry of foreign lawyers into American legal markets, ${ }^{65}$ permitting foreign governments an indirect voice in accreditation through state controlled law schools, ${ }^{66}$ and failing in a rigorous enough acculturation process that might require visits to the United States itself. ${ }^{67}$

The 2010 Kane Committee Report is both interesting and challenging. From an economic perspective the thrust of the Report makes sense for the United States. It repre-

\footnotetext{
${ }^{60}$ Id., at $1-2$.

${ }^{61}$ Report, supra, at 8.

${ }^{62}$ Report, supra, at 3-7.

${ }^{63}$ Id., at 4.

${ }^{64}$ Id.

${ }^{65}$ The Special Committee suggests that expansion of ABA accreditation to foreign law schools may "enlarge practice opportunities for foreign lawyers" and such expansion would provide no reciprocal benefit for lawyers educated in the U.S.

${ }^{66}$ The Special Committee also suggests that "political difficulties" could result from the ABA's denial of an application for accreditation, especially if the foreign school is government-sponsored. The Special Committee suggests that such difficulties may put pressure on the ABA as well as the Department of State.

${ }^{67}$ Lastly, the Special Committee address the possibility that, although they will study U.S. law, foreign law students, unlike students trained in the U.S., will not be exposed to U.S. culture and such a deficiency may undermine the applicant's ability to understand the development of U.S. law and professional ethics. Id., at 5.
} 
sents recognition of the character of markets in legal education, and seeks to privilege American participation by removing regulatory barriers to expansion of market share. From a political perspective there is much to commend the Report from the perspective of American policy. In an era when soft power is sometimes more effective than military intervention, dominating cultural markets and markets in legal ideology, methods and substantive law substantially leverages American power. More practically, the Special Committee notes that expansion of accreditation will clarify that U.S. schools approved by the ABA are permitted to operate branch campuses in an effort to further develop the international programs such schools currently operate. The result, the Special Committee contends, "would provide another opportunity for U.S. law schools to compete internationally in the legal market."From an internal power dynamics perspective it also works to benefit the richest, most influential and powerful actors within legal academia. Not every law school has the resources to open branches or establish the sort of ties that might lead to US accredited joint ventures with foreign law schools--and don't be surprised if many of these foreign ventures are not at least initially structured as joint ventures between U.S. law schools and foreign academic units. The rules would tend to cement the privilege of the upper tier of American law school and deepen the divide between the haves and "have-nots" of a formally egalitarian but functionally class structured system of American legal education. Lastly the emphasis on English also produces a strong socio-cultural effect by deepening the power of English as the global language. Values are easier to transmit through a common language than in translation.

Yet some of these powerful incentives to move forward with this enterprise from the American perspective might provide a caution to those on the receiving end of the transaction. It is not too long a path from harmonization to subordination and from guidance to domination. ${ }^{68}$ These efforts can be as intrusive in host states as the erection of military bases--and more effective because they are meant to be open and inviting rather than walled off and secured. On the other hand, the process suggests partnership. It is as likely that a great infusion of foreign voices into American programs will change the Americans as it will acculturate the foreigners. American culture is particularly susceptible to foreign influence--but American tend to absorb foreign influences and naturalize them within their own culture rather than avoid them as threats, at least inthe long run. Yet the effect an expansion of accreditation would have on domestic markets for law and legal education within host states remains a topic that is sorely neglected in the Report.

The Special Committee acknowledged that the current ABA Standards were developed with the understanding that law schools seeking accreditation were located in the U.S. As such, the Special Committee suggested that some Standards would need to be revised to make explicit the matters that otherwise are inherently assumed when accreditation activities are directed at a U.S. based school. The Special Committee also suggested that Standards requiring a "well-qualified" faculty be revised to ensure that faculty at foreign schools are predominantly U.S. trained and have earned a J.D. degree from an ABA-approved U.S. law school. Similarly, the Special Committee holds that if

\footnotetext{
${ }^{68}$ See, Haim Sandberg, Legal Colonialism-Americanization of Legal Education in Israel, GLOBAL JURIST: Vol. 10; Iss. 2; Art.6 (2010).
} 
the goal of accreditation expansion is to facilitate admission to the U.S. bar and enhance opportunities for foreign graduates to practice in the U.S., current Standards should be revised to ensure that curriculum is predominantly taught in the English language. To further facilitate readiness for U.S. practice, the Special Committee suggested that the Section consider requiring foreign students to complete some basic education of the American government system so as to be introduced to the social and political context in which U.S. law evolves.

To deal with potential political difficulties, the Special Committee recommended that the Section devise a clear policy to permit refusal to review (or a power to reject) an application and the grounds for such a refusal. The Special Committee suggested that such a policy will be of assistance not only in obvious situations such as applications from schools located in a country such as North Korea, Iran, or Cuba, but will also provide the Section with discretion to withhold accreditation where the cultural and legal values of the host state (where the applicant institution is located) is incompatible with those of the United States. Such incompatibilities may include a country's standards on academic freedom, faculty governance, and discrimination and diversity. This provision is particularly revealing. It suggests first the outward cultural project inherent in foreign accreditation. The object is not merely to provide an education in the mechanics of domestic law but to inculcate American legal values and its cultural paradigms on students. In a sense, the object exports the socialization goals of projects like those in Educating Lawyers ${ }^{69}$ to foreign students. But it also suggests a fear of the foreign, and of the transmission of incompatible foreign values into the body of domestic law.

The Special Committee also noted that there have been concerns raised as to whether expansion of accreditation would have any effect on the U.S. Department of Education's recognition of the ABA as the national accrediting body for U.S. law schools. The Special Committee noted, however, that "preliminary indications from our outside Counsel indicate the answer is no." The Special Committee was also aware of the concern that the expansion of opportunities for foreign-educated attorneys might create divides among individuals and different sections of the ABA but considered those concerns to be without merit, as "leadership of the ABA in the last several years has been very globally-minded."Lastly, the Special Committee addressed concerns over the economic burdens of expanding accreditation activities and suggested that, in addition to the costs being passed on to the applicant school, a pre-screening process before a site-inspection may avoid misunderstandings and the expense of time and resources.

3. The Management of Post Secondary Legal Education for Foreign Lawyers. The American Bar Association has recently considered the issue of the control of licensing requirements for American law schools offering post J.D. programs for foreign law graduates. ${ }^{70}$ The focus of the report and recommendations was on greater management controls, bureaucratization and regularization of offerings. ${ }^{71}$ The Committee noted that accreditation of LL.M programs has been suggested as a way to provide state supreme courts with the information needed to determine an applicant's eligibility for the bar

\footnotetext{
${ }^{69}$ SeeSection III, 1, supra.

${ }^{70}$ Honorable Elizabeth B. Lacy, Report of the Special Comm. on International Issues, 2009 A.B.A. Sec. of Legal Educ. and Admissions to the Bar (Lacy Report) http://www.abajournal.com/files/FINAL.pdf

${ }^{71}$ Seediscussion, supra, Section III, 2.
} 
exam. The Committee, however, suggested that the Section of Legal Education and Admissions to the Bar consider the development of criteria to be used to advise state supreme courts and bar administrators that an LL.M graduate, though receiving their primary degree in a foreign law school, was sufficiently educated in U.S. law and that the applicant should be allowed to sit for the bar exam. ${ }^{72}$ It explained that this approach, rather than full accreditation, would allow the ABA to make recommendations to state courts and bar administrators on "best practices" without requiring schools to change their current LL.M. programs and obfuscating the need for the ABA to develop a large scale accreditation process to replace its current "acquiescence review." ${ }^{73}$ However, the Committee recognized the possibility that U.S. graduates of non-accredited law schools might seek an LL.M. degree from an ABA accredited school that met the foreign criteria as a way to fulfill state accreditation requirements for eligibility for the bar. The Committee noted that this might be viewed as a way to circumvent the ABA accreditation requirements and would lead to different treatment of LL.M. graduates with a J.D. degree from a non-accredited school and foreign LL.M. graduates also seeking eligibility to the bar but lacking a U.S. law degree.

While the Lacy Committee's work provided context for these issues, the actual effort to institutionalize and, to some extent, bureaucratize, the standards for LL.M. degrees for foreign lawyers was undertaken by the ABA Committee on International Legal Education. ${ }^{74}$ That undertaking was motivated in part by a 2007 resolution of the Conference of Chief Justices ${ }^{75}$ that urged "the American Bar Association Section on Legal Education and Admissions to the Bar to consider developing and implementing a program to certify the quality of the legal education offered by universities in other common-law countries," the Committee on International Legal Education was charged to "draft a proposed Model Rule that would establish criteria for an LL.M. program designed to prepare the foreign lawyer for the practice of law in the United States." 76 In March 2011, the Committee released its Proposed Model Rule on Admission of Foreign Edu-

\footnotetext{
${ }^{72}$ The Lacy committee acknowledged this possibility in the context of the related work of the ABA Committee on International Issues, which eventually produced the model rule, discussed infra this Section. ${ }^{73} / d$.

${ }^{74}$ The American Bar Association describes theduties of thisCommittee as:

The Committee reviews and disseminates information regarding international developments and initiatives that have implications for legal education and bar admission in the United States, including developments to which the ABA Section of Legal Education and Admissions to the Bar may want to respond. The Committee works with other Section committees on subjects of mutual interest. The Committee may upon request from the Council furnish liaisons from the Section to other ABA entities with responsibilities in the fields of international legal education, bar admissions and the international practice of law. The Committee may make policy recommendations to the Council.
}

American Bar Association, Legal Education, Committees, available http://apps.americanbar.org/legaled/committees/committees.html.

${ }^{75}$ Conference of Chief Justices, Resolution 8 Regarding Accreditation of Legal Education in Common Law Countries by the ABA Section on Legal Education and Admissions to the Bar (Feb. 2007), http://ccj.ncsc.dni.us/LegalEducationResolutions/resol8AccredLegalEduc CommonLawCountries.html

${ }^{76}$ American Bar Association Section of Legal Education and Admissions to the Bar, Proposed Model Rule on Admission of Foreign Educated Lawyers.http://www.americanbar.org/content/dam/aba/administrative/legal education and admissio ns to the bar/council reports and resolutions/20110420 model rule and_criteria foreign lawyers. authcheckdam.pdf (accessed 7/1/11) 
cated Lawyers $^{77}$ and is welcoming public comments through July 15, 2011, at which point an evaluation and amendment process will commence in preparation for presentment to the ABA House of Delegates in February, 2012.

The Model Rule distinguishes between the regularization of the criteria for the awarding of LL.M. degrees suitable to meet the licensing requirements of states, and the obligation of the state licensing agency to permit applicants receiving such degrees to sit for the bar examination. An important objective of the Model Rule would shift the inquiry from a determination of the sufficiency of an applicant's foreign education to a determination of the applicant's domestic education in preparing the applicant for U.S. practice. Moreover, this proposal shifts the burden of the determination to the law school and away from the state court or bar examiner. That is, the proposed Model Rule would require the law school to certify not only that the applicant had completed a certified LL.M. program, but also that the applicant meets the Model Rule's requirements regarding foreign education and licensure. The Committee notes that this burden would be best satisfied at the time of admission to the certified LL.M. program and could be accomplished through a credential assembly service such as Law School Admissions Council (LSAC).

Thus, it is important to understand that the proposed Model Rule Purports to assist state supreme courts and bar examiners in two respects: (1) by shifting the focus of the inquiry away from a determination of the sufficiency of an applicant's foreign education as preparation for U.S. practice and, rather, onto the adequacy of preparation for U.S. practice obtained in a domestic LL.M. program; and (2) alleviating the logistical burden placed on state courts and bar examiners by requiring instead that law schools determine the status of the applicant's foreign education and licensure. The Committee also acknowledged that states with existing criteria for the admission of foreign educated lawyers to the bar examination may wish to continue to rely on that criteria and that, "the primary goal is to provide a Model Rule for those state courts that have not adopted requirements governing the admission of foreign lawyers." ${ }^{78}$

The key to this effort lies in the development of uniform criteria for the certification of LL.M. programs. Certification covers a large number of conditions. These include approval of law schools offering LL.M. degrees by the Council, minimum minutes of ins-

\footnotetext{
${ }^{77}$ THE MODEL RULE; If adopted by a state supreme court, the model rule would permit a lawyer educated at a foreign law school to take the bar examination if the foreign educated lawyer: (1) Received his or her legal education and graduated from a foreign law school that: (a) is government sanctioned or recognized, if educational institutions are state regulated within the country; or (b) is recognized or approved by an evaluation body, if such agency exists within the country; or (c) is chartered to award first degrees in law by the appropriate authority within the country; (2) is authorized to practice law in a foreign jurisdiction; and (3) has been awarded, by a law school fully approved by the Council, an LL.M. degree for the Practice of Law in the United States which has been certified by the Council as meeting the criteria established by the Council to qualify a foreign-educated lawyer to sit for the bar examination in a United States jurisdiction.

${ }^{78}$ Indeed, as of 2010, 32 U.S. jurisdictions have criteria governing the admission of foreign educated attorneys and 25 jurisdictions do not permit the admission of foreign educated attorneys under any conditions. National Conference of Bar Examiners and American Bar Association Section of Legal Education and Admissions to the Bar: Comprehensive Guide to Bar Admission Requirements, 2011, Chart 4. http://www.americanbar.org/content/dam/aba/migrated/legaled/publications/20110201_Comp_Guide .authcheckdam.pdf (accessed 7/1/11).
} 
truction in U.S. domestic law, the timing of instruction (must be taught during regular academic year), the qualifications of faculty, and length of program and disclosure issues. It is important to note that in addition to only being available to ABA accredited law schools, certification of a school's LL.M. program requires that the program largely teach curriculum typical of the first year of the JD program. Indeed, the Committee notes that while many ABA approved law schools have LL.M. programs designed to meet many educational goals, certification is only available for, and this criteria is designed to measure, programs operating with the goal of preparing students for the practice of law within the United States.

With this in mind, it would seem that the proposed LL.M. certification program might appear to foster globalization much more than the proposed accreditation of foreign law schools. That is, because bar exam eligibility for graduates of certified LL.M. programs requires that the applicant be a graduate of a foreign law school and authorized to practice law in the foreign jurisdiction, with regard to multi-jurisdictional practice and credential recognition, the proposed certification of LL.M. programs would appear to promote globalization of the legal profession and harmonization of legal systems. Moreover, under the LL.M. certification program, states will not feel the same pressure to adopt the ABA's proposal as they would in the event of an expansion of ABA accreditation. That is, because all states find eligible graduates from $A B A$ accredited law schools, states wishing to avoid the admission of foreign attorneys educated at an accredited foreign law school would be forced to rewrite state rules governing the admission of attorneys from ABA accredited law schools. However, under the LL.M. certification proposed Rule, states do not have the same incentive to adopt the rule and permit admission of foreign applicants simply because the logistical cost of doing so has been passed onto law schools.

Thus, without knowing what each individual state will do, it is impossible to gauge the effect this proposed Model Rule will have on the admission of foreign attorneys. That is, for states with liberal rules governing the admission of foreign attorneys currently in place, adoption of this rule may signal tighter restrictions. However, it is equally plausible that these states will resist the Model Rule, choosing instead to continue reliance on their own rules (which may be more liberal or stringent depending on the jurisdiction). ${ }^{79}$ On the opposite side of the spectrum, it is equally plausible that states that do not currently permit the admission of foreign attorneys may adopt the Model Rule, thus signaling a liberalization of rules governing the admission of foreign attorneys. Thus, although it is uncertain whether the proposed Model Rule will liberalize or tighten restrictions in the aggregate, it is likely that the Model Rule will shift the distribution of jurisdictions permitting admission of foreign attorneys. In any event, assuming enough jurisdictions adopt the Model Rule to make adjustments to LL.M. programs worth the expense, law schools may find the promise of increased interest in

\footnotetext{
${ }^{79}$ Indeed, New York's recently amended Section 520.6 of the Rules of the Court of Appeals for the Admission of Attorneys and Counselors at Law restricts historically liberal rules governing the admission of foreign attorneys but remains less stringent than the ABA's proposal. See, e.g., Notice to the Bar, Study of Law in Foreign Country; Required Legal Education, State of New York Court of Appeals, http://www.courts.state.ny.us/CTAPPS/news/nottobar/StudyofLawForeignCountry.pdf $\quad$ (accessed 7/1/11)
} 
LL.M. programs (and thus increased tuition dollars) a sufficient incentive to seek certification of their LL.M. programs.

Despite these financial incentives, it can be argued that the requirement that the LL.M. program teach first year curriculum may have the actual effect of driving students away from the LL.M. programs. ${ }^{80}$ That is, many LL.M. students have no desire to practice law in the United States and, rather, seek an LL.M. degree in a particular specialty to take back to their home jurisdiction. With this in mind, many students may be put off by the notion of taking courses other than those of their chosen specialty. Nevertheless, itmight be possible for a law school to circumvent this problem. The easiest way to avoid the problem is through the creation of two separate 'tracks' for foreign licensed LL.M. students. One would be crafted to meet the requirements for practice in the U.S. The other would be structured without the need to conform the program to the practice requirements of states. The difficulty would be one of resources and capacity; law schools may not have the resources to implement multiple post-J.D. programs or the capacity to make these programs financially viable.

Moreover, it is especially important to note that the LL.M. program must be completed in the U.S. Although many will argue that this requirement seems to promote exposure to U.S. custom and culture before practice (alleviating the concerns of many who oppose foreign accreditation), the cost of relocation, foregone wages, and the cost of living in the U.S. may serve as a substantial barrier to students seeking to practice there. Moreover, with many U.S. law schools already offering LL.M. programs abroad through branch campuses and partnerships with foreign universities, it is unclear why the Committee would require that the program be completed in the U.S. (especially in light of the fact that potential accreditation expansion would permit earning a JD without ever setting foot in the U.S.).

Additionally, there are already concerns that the adoption of this rule will raise equal protection concerns from U.S. law students from unaccredited law schools who are not eligible to sit for the bar exam. That is, it is important to recall that the model rule will require that, in addition to completing the certified LL.M. program, the bar applicant be a graduate of a foreign law school and licensed to practice in a foreign jurisdictionboth requirements that will not be satisfied by a U.S. law student from an unaccredited law school. In Matter of Tocci, ${ }^{81}$ the Supreme Judicial Court of Massachusetts held that equal protection was not violated when, despite a rule requiring bar applicants to be graduates of an ABA accredited law school, alternate approval procedures were utilized for foreign-educated applicants but not for domestic graduates of unaccredited law schools. That is, the court held that, because the ABA does not accredit foreign law schools, it is rational to provide an alternate procedure for foreign-educated bar applicants and equal protection does not prohibit the difference in treatment. This is a particularly interesting case in light of the ABA's current consideration of accrediting fo-

\footnotetext{
${ }^{80}$ "It sounds to me like students would be able to take the bar in other states, which is great for us...But I think the curriculum requirements would piss off a lot of our students who want to take more advanced courses like corporate finance." Stephen Presser, Raoul Berger Professor of Legal History, Northwestern University School of Law. Quoted in: Karen Sloan, ABA Proposes Big Changes for LL.M.S, LAW.COM (5/24/2011) http://www.law.com/jsp/law/LawArticleFriendly.jsp?id=1202494952850 (accessed 7/1/11). ${ }^{81}$ Matter of Tocci, 600 N.E.2d 577 (MA, 1992)
} 
reign law schools. That is, if the $A B A$ decides to implement this rule and also begins accrediting foreign law schools, a court facing an equal protection challenge will have to modify or avoid using all together the rationale of Tocci.

4. Accreditation of Foreign Law Schools Globalization v. Legal Colonialism. At the most general level, it can be argued that the expansion of $A B A$ accreditation to foreign law schools is inapposite to the internationalization of law. Yet foreign accreditation fits well within a globalization model. The difference is between an effort to create a new common standard that represents a common position (internationalization) and an effort to universalize a dominant system of domestic law, transforming it from merely the expression of a domestic legal order to using it as a basis for global legal convergence.

The ABA has been at the forefront of globalization (rather than internationalization) efforts. Its "rule of law" initiative provides an important case in point. ${ }^{82}$ Started about the time of the disintegration of the Soviet Union, the ABA's initiatives are meant to serve as directed programs of legal reforms. ${ }^{83}$ These reform efforts are grounded, but only in part, on the insights and frameworks of U.S. domestic law and theory. ${ }^{84}$ The ABA Rule of Law Initiative is guided bya set of five core principles that are meant to provide framework and methodology. ${ }^{85}$ These efforts have produced substantial positi-

82 "The ABA Rule of Law Initiative is a public service project of the American Bar Association dedicated to promoting rule of law around the world. The ABA Rule of Law Initiative believes that rule of law promotion is the most effective long-term antidote to the pressing problems facing the world community today, including poverty, economic stagnation, and conflict." American Bar Association, Rule of Law Initiative, Home, available http://apps.americanbar.org/rol/.

83 "Today, ABA ROLI implements legal reform programs in more than 40 countries in Africa,Asia, Europe and Eurasia,Latin America and the Caribbean, and the Middle East and North Africa. The ABA Rule of Law Initiative has more than 400 professional staff working in the United States and abroad, including a cadre of short- and long-term expatriate volunteers who, since the program's inception, have contributed more than $\$ 200$ million in pro bono technical legal assistance." American Bar Association, Rule of Law Initiative, About, available http://apps.americanbar.org/rol/about/.

84 "Countries that lack the rule of law very often fail to meet the most basic needs of their populations. In fact, over half of the world's population lives in countries that lack the rule of law, consigning billions of people to lives characterized by a lack of economic opportunity, basic justice and even physical security. Addressing this global rule of law deficit is not only the most important calling of the world's legal community; it must also become an urgent priority for world leaders, international institutions and citizens committed to making this a just, peaceful and prosperous world." American Bar Association, Rule of Law Initiative, About, Our Core Principles, available http://apps.americanbar.org/rol/about/.

${ }^{85}$ Thefivecoreprinciplesinclude:

1. Employing a highly consultative approach to the delivery of technical assistance that is responsive to the requests and priorities of the Initiative's local partners.

2. Employing a comparative approach in the provision of technical legal assistance, with the U.S. legal system providing just one of several models that host country reformers can draw upon.

3. Providing technical assistance and advice that is neutral and apolitical.

4. Building local capacity by strengthening institutions in both the governmental and nongovernmental sectors and by furthering the professional development of ABA ROLI's host country staff, many of whom become the next generation of leaders in their countries.

5. Providing thought leadership in the field of rule of law promotion that draws on both ABA ROLI's extensive overseas field experience and on the resources and convening power of the ABA and its more than 400,000 members in the United States and abroad.

American Bar Association, Rule of Law Initiative, About, Our Core Principles, available http://apps.americanbar.org/rol/about/. 
ve results, by helping to reframe local efforts at law reform with reference to consensus-based ideas useful to the development of indigenous legal cultures. ${ }^{86}$ These sorts of law culture exportation efforts are not unique to the United States. The European Union itself has attempted a similar project. ${ }^{87}$ The political agenda to be achieved through law reform is not masked, for example, the European initiative is said to have "the potential to be more than an ill-resourced additional fragment of the EU's engagement with Central Asia.. . . In a region where the living conditions can force societies to challenge their political regimes in search of a better political order, the EU should stand for a credible alternative by furthering values such as the rule of law." ${ }^{\prime 8}$

But such initiatives have also been subject to criticism. "Rule of law aid specialists often assume that cultural issues are of peripheral importance to their work. Consequently, they lack a vital analytical component when they seek to understand why new laws are not implemented. Sometimes the resistance to implementation and acceptance comes from cultural predispositions, not some technical failure of implementing and supporting institutions." ${ }^{190}$ As a general matter, there is a sense in these criticisms that sometimes rule of law initiatives like these are to transplant the sensibilities and values of North American and European states rather than help develop indigenous institutions. ${ }^{91}$ As such, rule of law initiatives, like other endeavors grounded in the importation of rules or frameworks from some other place-even when generalized-can represent a means by which local cultures are altered along the lines of the imported system. ${ }^{92}$

Likewise, globalization through accreditation of foreign law school programs might not serve the objectives of internationalization, but rather would serve to globalize (and perhaps universalize) the frameworks of a particularly dominant national legal order. Thus, although the objective of exposing foreign students to the American legal system may be a desirable ingredient in the globalization of law, it may accomplish more than that. The Kane report's suggestion that the curriculum be predominantly U.S. law

\footnotetext{
${ }^{86}$ See, e.g., Jenny H. Peterson, "'Rule of Law' Initiatives and the Liberal Peace: The Impact of Politicised Reform in Post-Conflict States," Disasters 34: S15-S39 (2010).

${ }^{87}$ See, Martin Schuster, "The EU's Rule of Law Initiative for Central Asia: From Initiative to More Substance?, EUCAM Policy Brief No. 18, June 2011. The EU rule of law strategy in Central Asia "presents itself as the political superstructure to the Commission's development strategy." Id.

${ }^{88}$ Id., at 4.

${ }^{89}$ See, e.g., Wade Channell, Lessons Not Learned Problems with Western Aid for Law Reform in PostcommunistCountries4 (Carnegie Endowment for Int'I Peace, Democracy and Rule of Law Project, Working Paper No. 57, March, 2005) available at http://www.carnegieendowment.org/2005/04/26/lessonsnot-learned-problems-with-western-aid-for-law-reform-in-postcommunist-countries/cgx; Rachel Kleinfeld Belton, Competing Definitions of the Rule of Law 3 (Carnegie Endowment for Int'I Peace, Democracy and Rule of Law Project, Working Paper No. 55, Jan., 2005) available at http://www.carnegieendowment.org/files/CP55.Belton.FINAL.pdf.

${ }^{90}$ Channel, supra note 77 , at 9.

${ }^{91} \mathrm{Cf}$., VardaHussain, Note, Sustaining Judicial Rescues: The Role of Outreach and Capacity-Building Efforts in War Crimes Tribunals, 45 Va. J. Int'I L. 547, 551-58 (2005).

${ }^{92}$ See,e .g., Adolfo CéspedesZavaleta, The Impact of the U.S. Legal System on Peruvian Administrative Law, in Ronald A. Brand and D. Wes Rist, eds., The Export of Legal Education (Fanham (Surry, UK): Ashgate 2009).
} 
taught in English, ${ }^{93}$ for example, also suggests that an expansion of accreditation to foreign law schools might also naturalize American domestic law cultures within the domestic legal orders of host states. This is a far different project from that of rather than internationalizinglegal education along the lines described in the preceding section; grounded in a competitive markets model rather than a cooperative and managed model. ${ }^{94}$ Despite the suggestion in the ABA reports that an expansion of accreditation will serve to assist state supreme courts, and thus suggests the end goal of facilitating the inclusion of foreign lawyers in American practice, it is unlikely that all graduates of ABA accredited foreign law schools will end up practicing in the U.S. That said, many of these graduates, now educated only in U.S. law, may seek to teach in their home jurisdiction, hold political office, etc. which may permit their predominantly American education to influence and effect the laws and policies of their home jurisdiction. In his article Legal Colonialism-Americanization of Legal Education in Israel, Haim Sandberg suggests that the application of American law, developed and founded in American culture, history, and values, may not comport with the history, tradition, values, and culture of the foreign jurisdiction. ${ }^{95}$ The issues may present themselves in particularly acute forms in post-conflict states. ${ }^{96}$ Similarly, graduates of ABA accredited foreign law schools, educated in a law other than that which is borne from and rooted in the history and culture of their nation, may influence the legal landscape of theirhomejurisdictions throughattempts to apply American precedent to unique foreign issues and policy concerns.

Though it can be argued that this cultural exchange will eventually balance out as foreign graduates relocate to practice in the U.S., because the Kane Committee requires that the curriculum be predominantly U.S. law it is not unlikely that many of these foreign graduates will have little academic or professional exposure to the legal system of their home jurisdiction and thus little knowledge of foreign law by which to reciprocally influence U.S. law. More importantly, teaching American law in host states may be designed specifically to further additional goals, not the least appreciated of which is the development of rule of law principles. ${ }^{97}$ Additionally, because recent trends have led many nations to classify and recognize legal education as a post-graduate program, ${ }^{98}$ and in light of the relative cost of graduate education, it is unlikely that appli-

\footnotetext{
93 Mary K. Kane, Report of Special Comm. on Foreign Law Schools Seeking Approval Under ABA Standards, 2009 A.B.A. Sec. of Legal Educ. and Admissions to the Bar (Kane Report). § II at 5, 6, 7.http://www.abajournal.com/files/kanereportinternational.pdf

${ }^{94}$ Seediscussion, supra, Section II.

${ }^{95}$ Haim Sandberg, Legal Colonialism-Americanization of Legal Education in Israel, GLOBAL JURIST: Vol. 10; Iss.2; Art.6 (2010).

${ }^{96}$ See, e.g., Augustine S.J. Park, "Peacebuilding, the Rule of Law and theProblem of Culture: Assimilation, Multiculturalism, Deployment," Journal of Inrevention and Statebuilding4(4):413-432 (2011).

${ }^{97}$ See, e.g., Naveed Ahmad, Designing and Implementing a Legal English CoursetoDevelopthe Rule of Law in theContext of Transition in PakistaniSociety, in Ronald A. Brand and D. Wes Rist, eds., TheExport of Legal Education (Fanham (Surry, UK): Ashgate 2009).

98 “The 1999 Bologna Declaration of the European Ministers of Education suggests, to put it simply, a restructuring of higher education by a uniform 3/5/8 year sequence of degrees (e.g., the "Bologna Process"), following suit with the classical American college and university education model. It therefore starts with a bachelor's degree, possible after three years of studies." See, e.g., Norbert Reich, Recent Trends in European Legal Education: The Place of the European Law Faculties Association, 21 PENN ST. INT'L L. REV. 21 at 29 (2002).
} 
cants to an ABA accredited foreign law school will have already completed postgraduate education in the law of their home jurisdiction. Thus, although it is likely that the influx of foreign attorneys will have some influence on the American legal profession, it is unlikely that this influence will have the same affect on the law itself as the export of American law to overseas schools will have on foreign legal systems.

Conversely, globalization is naturally going to favor those systems of law belonging to the nation states with the most power and control over the industry. That is, it can be argued that it is undesirable to seek to achieve globalization that is an equal blend of all systems of law merely for the sake of equality. Rather, it can be argued that globalization should seek to maximize trade and stimulate the global economy and, as such, the markets and nations with the strongest influence on global trade will necessarily be those that are most strongly represented in globalization efforts. Following from that argument, because "global" law firms are predominantly extensions and branch campuses of American law firms ${ }^{99}$ and America is a major (if not the most major) player in the international business world, it is not surprising that the American legal system would be central to efforts to globalize the legal profession. Thus, when speaking of globalization of law, the trends in legal education are going to mirror those of the industry. To put it simply, trends in globalization are going to follow the moneybecause that money is predominantly U.S. currency generated by the business of U.S. multinationals that is coordinated and developed with the assistance of U.S. law firms, it is no shock that globalization efforts may appear to favor American law. As such, the real question becomes: "Where is the line between actual legal colonialism and globalization that merely appears to be colonialism due to the enormous size and influence of American law globally?"

In either case, the genesis of the accreditation efforts is nationalist in origin, and market oriented in framing its methods. Ironically, the nationalist globalization approach to legal education expansion has met with internal resistance as well. ${ }^{100}$ At its December 4th, 2010, meeting, the Council unanimously voted to postpone consideration of any foreign applications for accreditation, stating:

"Consistent with the first recommendation of the Kane Committee report and in view of the comments received by the Council with respect to that report, I move that the Council continue with its consideration of the approval of foreign law schools and engage in our consideration appropriate public and private stakeholders, for example, the CCJ [Conference of Chief Justices], state bar examiners, legal educators, representatives of the legal profession, and public officials. Until the Council has fully vetted the issue as to whether to expand the accreditation role of the Section to encompass law

99 See, e.g., The Global 100 2010: The Worlds Highest Grossing Law Firms, American Lawyer, http://www.law.com/jsp/tal/PubArticleTAL.jsp?id=1202472338838 (Accessed 7/1/11) (Seventy-nine of the worlds 100 highest grossing law firms are U.S. based firms)

100 In August of 2010, the Special Committee on Foreign Law Schools Seeking Approval under ABA Standards presented its report to the Section of Legal Education and Admission to the Bar at the Section's annual meeting. The Council invited public comment through mid-October and received over $60 \mathrm{com}-$ ments, most in opposition of the Special Committee's proposal. See, Comments on Accreditation of Foreign Law Programs, AmericanBar.org, http://apps.americanbar.org/legaled/accreditation/Comments on Accreditation of Foreign Schools.html (last visited Feb. 27, 2010) 
schools located outside of the U.S. and its territories, the section will not proceed with consideration of any application for provisional approval from a foreign law school."101

This section concludes with an analysis of that opposition.

i. The opposition has argued that expansion of accreditation does not serve the purposes articulated by the committees nor the mission of the ABA as an accrediting agency. Although the Lacy Committee notes that a recent survey demonstrates state support of the ABA's initiative, the Committee fails to note that the results of the survey indicate that a majority of states surveyed were interested in merely "receiving more information about foreign legal education, foreign admission rules, and foreign character and fitness requirements." ${ }^{102}$ As noted, while this data may suggest that states do have some concern as to determining the eligibility of foreign applicants, the questionnaire does not demonstrate that states would welcome foreign accreditation as a means by which to gauge applicant eligibility. Similarly, the Committee cites the Conference of Chief Justices passing of Resolution 8 as demonstrative of state interest in the ABA's involvement in the decision-making process; however, the resolution explicitly urges the Section to "consider developing and implementing a program to certify the quality of the legal education offered by universities in other common-law countries," ${ }^{\prime 103}$ and does not mention accreditation at all. Because accreditation of foreign law schools is a much different task than the development and implementation of a certification program, it may be argued that if the CCJ regarded expansion of accreditation as a viable option it would have been reflected in Resolution 8.

Moreover, the Kane Committee notes that, "because these decisions will be made from state to state, there will not be just one standard for evaluating educational credentials... [and] that will result in a lack of clarity and consistency." ${ }^{104}$ Although concern for consistency is admirable, the Committee fails to recognize that eligibility determinations have always been with the states and state-by-state differences merely "reflect respective policy judgments of those states as to the need for and desirability of having foreign trained attorneys admitted to the bar." ${ }^{105}$ Indeed, although the Committee points out that New York and California have been most affected by an increase in the number of foreign applicant's, the New York State Bar Association opposes the possibility of foreign accreditation noting, "it is not clear that there is any overpowering reason why a single, national standard procedure is desirable for what is at its core a state-specific decision," ${ }^{106}$ and that, instead, "it might be especially helpful if...there

\footnotetext{
${ }^{101}$ See American Bar Association, Press Release, ABA Now, ABA Legal Education Section Delays Decision on Accrediting Foreign Law Schools, (Dec. 4, 2010) http://www.abanow.org/2010/12/aba-legaleducation-section-decides-to-continue-consideration-of-whether-to-accredit-foreign-law-schools/ ${ }^{102} / d$. at 11

${ }^{103}$ Id. 12

${ }^{104}$ Kane Report at 3

${ }^{105}$ Email from Michael M. Martin, Interim Dean and Distinguished Prof., Fordham Univ. School of Law, to Hulett Askew, Consultant of Legal Educ., Sec. of Legal Educ. and Admissions to the Bar (Oct. 13, 2010) http://apps.americanbar.org/legaled/accreditation/Comments on Foreign Program Accreditation/Fordham.pdf

${ }^{106}$ Letter from New York State Bar Assoc. Comm. on Legal Educ. \& Admission to the Bar, to ABA Council of the Sec. of Legal Educ. (Oct. 22, 2010) http://apps.americanbar.org/legaled/accreditation/Comments on Foreign Program Accreditation/NYSBAOct 2010.pdf
} 
were a nationally accessible agency that would evaluate and authenticate the credentials of foreign candidates for the bar." ${ }^{107}$ This contention, that eligibility standards should be determined by the states in accordance with their individual needs, may account for the Committee's observation that states have been slow to adopt the few policies the $A B A$ has promulgated regarding domestic practice of foreign-educated attorneys. $^{108}$

ii. In addition to echoing the Lacy Committee's contention that state supreme courts would benefit from an expansion of accreditation, the Kane Committee notes that willingness to expand accreditation to schools embracing the American model is an appropriate way to improve the training of lawyers globally and contribute to the modern economy and the international legal profession. ${ }^{109}$ The Kane Committee also was at pains to emphasize the methods by which U.S. law schools could expand abroad without loss of the economic value of accreditation and therefore would provide another opportunity for U.S. law schools to compete internationally. ${ }^{110}$ Yet, while accreditation of foreign law schools may "clarify" that U.S. law schools are permitted to open branch campuses overseas, it is unclear just how the Committee envisions that such an expansion would "provide another opportunity for U.S. law schools to compete internationally."

Yet the contention can be turned on its head. Accreditation of foreign law schools could also have the effect of reducing incentivesof domestic law schools to open branch campuses. That is, it is not unreasonable to assume that, when faced with a choice between an ABA accredited foreign law school and the branch campus of a U.S. law school, a foreign student may find a better bargain and may feel more comfortable in the foreign school. However, the Committee may be correct that an expansion of accreditation will better position U.S. law schools to compete internationally insomuch as, because our nation's top law school's parent universities have, in many cases, already expanded to many foreign nations, expanding accreditation to foreign law schools may signify the green-light for large universities to undertake an even fuller expansion of their overseas legal offerings. That is, an expansion of accreditation activities to foreign law schools may incite a race for U.S. law schools to plant their flag in as many countries as possible and as fast as possible, lest the home country beat them to it. ${ }^{111}$

Moreover, because the ABA standards would require a foreign law school seeking ABA accreditation to provide "substantial instruction in the U.S. substantive law generally regarded as necessary to effective and responsible participation in the U.S. legal profession," ${ }^{112}$ it is unclear, absent a blatant assertion that U.S. law is superior to any other law, just how legal education can be globally improved by an expansion of accreditation. Rather, the Section's proposal has been criticized as being "anti-scholarly" and detracting from, rather than enriching, legal education on a global scale. That is, it can be argued that expansion of accreditation, and the resultant focus on U.S. law in over-

\footnotetext{
${ }^{107}$ Id. at 7

${ }^{108}$ Lacy Report at 8

${ }^{109}$ Kane Report $§ \mathrm{IA}(4)$

${ }^{110}$ Id. at $\S \mathrm{IA}(6)$

${ }^{111}$ This justification/ implication may also be viewed as beyond the scope of the Accreditation Project

${ }^{112}$ Kane Report § IIA(1)
} 
seas institutions, may potentially undermine the efforts and work of those "working towards true globalization of U.S. legal education, through faculty and student exchanges, LL.M and joint degree programs, and the recruitment of foreign J.D. students to inform and enrich the experience of learning, teaching, researching and understanding domestic, international and comparative law." ${ }^{113}$ That is, "legal education in the U.S. attracts thousands of foreign nationals each year pursuing LL.M. and J.D. degrees...accrediting legal education in other countries is the surest way to reverse this trend. ${ }^{\prime 114}$ Moreover, there is an argument that an expansion of accreditation to foreign law schools would require implementation of accreditation standards that may weaken the current shift by U.S. schools from predominantly doctrinal curriculum to practical clinical curriculum. ${ }^{115}$

Since the Lacy Committee only suggested expansion of accreditation to foreign law schools already modeling their programs under current ABA Standards, however, it has been argued that there is no reason not to accredit such schools based simply on geography. In the words of Jeffrey Lehman, chancellor and founding dean of the School of Transnational Law at Peking University, the question becomes: "whether the ABA should refuse to follow the ordinary rules of procedure for approving a law school that satisfies all of the prevailing accreditation standards, solely because that law school is located outside the United States." ${ }^{116}$ However, the proposal to expand accreditation to foreign law schools comes at a time when the existing ABA accreditation standards are undergoing a comprehensive review that considers a substantial deregulation of U.S. law schools. Though such proposals are not finalized, the Clinical Legal Education Association noted that "one danger of adoption of the Special Committee's recommendation [to accredit foreign law schools] is that the Council will take on the perhaps insuperable burden of regulating legal education across a range of legal systems and cultures as it deregulates schools on its own soil." ${ }^{117}$ More practically, in light of the comprehensive review of accreditation standards, the Committees don't seem to recognize the logistical difficulties in ensuring foreign schools compliance with ABA standards. That is, "distance will inevitably make it more difficult to get a true handle on what is happening at these foreign law schools. This will lead to increased emphasis on quantitative and objective measures of a law school's performance. Yet if history has

\footnotetext{
${ }^{113}$ Email from Marcella David, Assoc. Dean for Int'l and Comparative Law, Univ. of lowa College of Law, to ABA Sec. of Legal Educ. and Admissions to the Bar (Sept 21, 2010) http://apps.americanbar.org/legaled/accreditation/Comments on Foreign Program Accreditation/MarcellaDavid.pdf

${ }^{114}$ Letter from Peter Joy, Prof. of Law, Washington Univ. in St. Louis School of Law, to Hulett H. Askew, Consultant on Legal Educ., Sec. of Legal Educ. and Admissions to the Bar (Sept. 20, 2010) http://apps.americanbar.org/legaled/accreditation/Comments on Foreign Program Accreditation/PeterJoy.pdf

${ }^{115}$ See Carnegie Foundation Report: Educating Lawyers: Preparation for the Profession of Law.

${ }^{116}$ Letter from Jeffrey Lehman, Chancellor and Founding Dean, Peking University School of Transnational Law, to The Council of the Sec. of Legal Educ. and Admissions to the Bar (Oct. 15, 2010) (Emphasis in original) http://apps.americanbar.org/legaled/accreditation/Comments on Foreign Program Accreditation/Peking University.pdf

$\frac{117}{11}$ Letter from Robert R. Kuehn, President, Clinical Legal Education Association, to Hulett H. Askew, Consultant on Legal Educ., Sec. of Legal Educ. and Admissions to the Bar (Oct. 15, 2010) http://apps.americanbar.org/legaled/accreditation/Comments on Foreign Program Accreditation/CLEA.pdf
} 
taught us anything it's that the essence of a sound legal education is a largely qualitative phenomenon." ${ }^{118}$

Thus, although Mr. Lehman's argument that a school meeting all current ABA accreditation standards should not be refused accreditation based on its location seems reasonable, it seems wise that the Section should postpone consideration of accreditation of foreign law schools until a review of such standards is complete. Moreover, the unique logistical, cultural, and political challenges of accrediting a law school in a foreign country makes it unlikely that standards for U.S. law schools will be sufficient for the evaluation of a foreign law school. Thus, while Mr. Lehman is right that: "The fact that some foreign law schools may fail to satisfy the Standards is not a reason to refuse to follow the standard procedures... [but rather] should lead to rigorous application of the Rules of Procedure and the Standards, not to a blanket refusal to apply them at all," ${ }^{119}$ deregulation might produce its own adverse consequences.

Thus a difficulty: should the review of current accreditation standards lead to the deregulation of U.S. law schools, satisfaction of ABA standards at that point, given the unique challenges of a foreign law school, would almost certainly be inadequate for ensuring the quality of education provided by a foreign law school. That is, in the midst of a comprehensive review and renovation of $A B A$ accreditation standards, it seems foolish to hastily consider accreditation of foreign law schools "that meet all of the prevailing Section Accreditation Standards." ${ }^{120}$ From this perspective, it is possible to argue that the Section's consideration of an expansion of accreditation might be premature. Although the Lacy Committee acknowledged several alternatives to facilitate the inclusion of foreign-trained attorneys in the U.S. legal profession, these alternatives have not been fully considered, except the consideration by the International Issues Committee of the certification of LL.M. degrees discussed above, and any decision concerning whether to proceed should be postponed until the Committee on International Issues, as well as other various entities within the ABA and Department of Education, have been consulted.

Moreover, and perhaps most importantly, even if the Section decided that an expansion of accreditation is the best method by which to fulfill the Committees' stated purposes, the Section should bear in mind that the Lacy Committee has only recommended proceeding with accreditation of those foreign law schools seeking accreditation that have met all requirements of current $A B A$ accreditation standards. The difficulty with this position, naturally, is its underlying purposes; though the focus of the consideration is on the process of conformity to standards (and thus procedural in character), it will inevitably also achieve a substantive effect. Certainly, sophisticated partici-

\footnotetext{
${ }^{118}$ Letter from Jeremy Paul, Dean, University of Connecticut School of Law, to Hulett Askew, Consultant on Legal Educ., Sec. of Legal Educ. and Admissions to the Bar (Oct. 15, 2010) http://apps.americanbar.org/legaled/accreditation/Comments on Foreign Program Accreditation/Jeremy Paul.pdf

${ }^{119}$ Letter from Jeffrey Lehman, Chancellor and Founding Dean, Peking University School of Transnational Law, to The Council of the Sec. of Legal Educ. and Admissions to the Bar (Oct. 15, 2010) (Emphasis in original) http://apps.americanbar.org/legaled/accreditation/Comments on Foreign Program Accreditation/Peking University.pdf

${ }^{120}$ Kane Report at 8
} 
pants in collaborative politics understand that an effective method of opposing a project is to induce its adherents to study it to death. Time changes circumstances, the pace of events moves interest from the object of study to some other goal, and the distraction of study might very well bury the project entirely.

iii. Another point of criticism centered on the failure of the Committee to distinguish between efforts to facilitate admission to the bar generally and efforts to facilitate admissions to the barin order to facilitate the greater objective of practice within the United States. Although the Committee is clear in their belief that an expansion of accreditation would assist states in determining a foreign applicant's eligibility to sit for the bar exam, the Committee is ambiguous in identifying the greater purpose admission to a state bar will serve; thus it is one thing to sit for the bar exam, it is quite another to be prepared for the practice of law in that jurisdiction. That is, the Committee notes that "some foreign law school programs report interest in ABA accreditation, not so that their graduates can practice in the United States, but effectively as a 'seal of approval' to obtain international recognition," and that "this rationale for expansion of accreditation [is] insufficient to recommend that the ABA develop standards for assessing those programs."121 The Committee's failure to make clear whether the goal of accreditation of foreign law schools is to provide eligibility to sit for a U.S. bar exam or if eligibility to the bar is simply a necessary step in satisfying the greater purpose of facilitating practice in the U.S. raises serious questions and merits brief discussion.

On the one hand, if the true purpose of foreign accreditation is the facilitation of practice in the U.S., expansion of accreditation does not seem necessary as a substantial number of U.S. law schools offer international students the opportunity to earn a J.D. in the U.S. Simply, a student wishing to practice in the U.S. has no reason to delay an inevitable trans-continental relocation and the Section has no incentive to facilitate such a delay. Further, adding to the pool of attorneys practicing in the U.S. seems ill advised at a time when U.S. grads are struggling to find employment. Lastly, its not clear how the Committee suggests distinguishing between the 'seal of approval' schools and graduates and those truly interested in admission to the bar and/or practice in the U.S. Arguably, a fair number of U.S. law graduates never take the bar exam or practice law in the traditional sense. It seems unreasonable and impractical to attempt to discern the motives of foreign law students and even more difficult to establish the line between ineligible 'seal of approval' schools and schools that are eligible for accreditation. That is, just what percentage of a foreign law school's student body should be committed to practice in the U.S. before the ABA considers accreditation of the school?

Yet, if the true purpose of expansion is simply to provide means by which to qualify for admission to the bar (regardless of whether the applicant intends to practice stateside), an argument can be made that an expansion of accreditation activities merely encourages outsourcing and circumvents the current practice of fly-in fly-out legal work. Such a possibility, outsourcing of legal jobs at a time when U.S. law graduates are struggling to find employment, is the focus of a substantial number of comments submitted in response to the Kane Committee's recommendations to the Section. That

${ }^{121} / d$. at 26 
is, the Committee has not addressed the possibility of foreign-trained attorneys traveling to the U.S., passing a state's bar exam, and returning home to practice offsite for a U.S. law firm. Although not specifically speaking of outsourcing, former ABA President Carolyn Lamm hinted at some of these arguments stating: "Great lawyering cannot be commoditized." 122 Regardless of the "truth" of "purpose," it is clear that there is concern that accreditation of foreign law schools may provide unequal opportunities, be it in outsourced or stateside practice, that will further impair U.S. graduates already struggling to find work. Specifically, the Kane reportnotes that expansion of accreditation "could result in enlarging practice opportunities for foreign lawyers...without any reciprocity or parallel opportunities provided by other countries for U.S. lawyers." ${ }^{123}$

This concern for the employment prospects of U.S. law graduates, however, fails to recognize that the U.S. Department of Education "requires the accreditation project to remain separate and independent from the parent American Bar Association"124 and, as such, any action of the accreditation project should be "designed, developed, and implemented for the purpose of advancing the basic goal of providing a sound program of legal education." ${ }^{125}$ It is not surprising,then, that the Committees have not directly addressed the issue of legal outsourcing and any effect an expansion of accreditation to foreign law schools would have on the legal process outsourcing industry. Indeed, in 1994, a Department of Justice investigation of the ABA led to an antitrust action against the ABA alleging a violation of the Sherman Act and the ABA's 1996 consent decree requiring the $A B A$ to renovate the accreditation process. ${ }^{126}$ However, as the next section will demonstrate, an expansion of accreditation to foreign law schools is not without its barriers. Although efforts to expand legal services to match the globalization of trade generally, implications of state sovereignty may challenge the ABA's efforts to participate in expanding access to the U.S. legal system.

122 Memorandum from Carolyn Lamm, Immediate Past President, ABA, to Judge Christine M. Durham, Chair, Sec. of Legal Educ. and Admissions to the Bar (Nov. 23, 2010) http://apps.americanbar.org/legaled/accreditation/Comments on Foreign Program Accreditation/CarolynLamm.pdf

${ }^{123}$ Kane Report at 5

${ }^{124}$ Sandy D'Alemberte, Report of the Law School Accreditation Task Force, 2009, ABA Sec. on Legal Educ. and Admissions to the Bar, at 1

125 Memorandum from Jerry Hafter, Honorable Christin Durham, and Dean John O'Brien to Sandy D'Alemberte (10/8/09) http://apps.americanbar.org/legaled/section/AC-taskforcereport.pdf. That is:

When acting on matters outside the Accreditation Project, the Council has the freedom to explore a range of considerations including a matter's impact on the $A B A$, on individual $A B A$ members, on the legal profession, on the Section's status or reputation within the $A B A$, and on internal ABA politics. When acting on matters to do with the Accreditation Project, the Council actions are more circumscribed.

Email from Irv Freeman to Chair Durham and Members of the Council (Aug. 31, 2010) http://apps.americanbar.org/legaled/accreditation/Comments on Foreign Program Accreditation/Irv Freeman.pdf

${ }^{126}$ See Mathew D. Shaver, Lifting the Veil: an Expose on the American bar Association's Arbitrary and Capricious Accreditation Process, 49 Wayne L. Rev. 1, (2003) 
iv. Lastly, issues of state sovereignty in the regulation of legal services may present an obstacle to the full implementation of foreign law school accreditation. ${ }^{127}$ The $A B A$ has not made it clear whether an expansion of accreditation to foreign law schools aims to assist state supreme courts in determining applicant eligibility for the greater purpose of facilitating domestic practice, or merely to facilitate eligibility for the bar. Given this failure to distinguish, this section will explore the effects accreditation would have on both types of practice. That is, the effects an expansion of accreditation would have on what the General Agreements on Trade in Services (GATS) refers to as Mode 4 supply, "by a service supplier of one Member, through presence of natural persons of a Member in the territory of any other Member", and the effects expansion would have on GATS Mode 1 supply, "From the territory of one Member into the territory of any other Member."128

The greatest barriers facing foreign-educated attorneys wishing to practice law in the U.S. are state bar regulations requiring an applicant to have been educated at an ABA accredited law school. Though not every jurisdiction requires applicants to have received their primary legal education at an ABA accredited law school, at the very least, applicants wishing to practice in the U.S. must meet additional requirements such as supplemental education at an ABA accredited school (LL.M), legal education from an English common law country, or licensure in their home jurisdiction. While I agree that three years of education at a foreign law school teaching U.S. law should be sufficient to remove these requirements, the change from the status quo is not monumental. That is, it is unclear just why these students would opt to delay a transcontinental move for three years and miss an opportunity to acculturate to the U.S. before practicing when a substantial number of U.S. law schools admit international students seeking a U.S. law degree. However, giving the benefit of the doubt to the ambiguous purpose articulated by the Lacy and Kane committees, an exploration of the reverse type of practice, GATS Mode 1 supply, is merited and, indeed, reveals a much bigger effect on the status quo.

GATS Mode 1 supply "is involved whenever foreign lawyers create a legal product or advice, which is then sent from outside the country to clients inside the country" ${ }^{\prime 29}$ Though not perfectly on point, or at least not framed in this way, GATS Mode 1 appears to apply to, inter alia, legal process outsourcing (LPO). Though not a new phenomenon, legal process outsourcing refers to "sending work to a more efficient and costeffective location, but the outsourced work has no legal relationship to the jurisdiction where the work is sent." ${ }^{\prime 130}$ As with outsourcing in general, the draw of "cutting costs and increasing efficiency" ${ }^{131}$ has made legal process outsourcing a \$250 million a year

\footnotetext{
${ }^{127}$ Moreover, although there may be many positive aspects to the proposed certification of LL.M. programs, the structure of the proposed program may create substantial barriers to trade in services. This aspect is suggested by the analysis above but is not discussed further here.

${ }^{128}$ Laurel S. Terry, From GATS to APEC: The Impact of Trade Agreements on Legal Services, 43 Akron L. Rev. 875, 913 (2010) (citing: The General Agreement on Trade in Services, Article VI (4))

${ }^{129}$ IBA GATS Handbook at 23

${ }^{130}$ Ronald D. Rotenda\& John S. Dzienkowski, Legal Ethics: A Lawyer's Deskbook on Professional Responsibility § 5.3-2 n.6 (2009-2010)

${ }^{131}$ Alexandra Hanson, Legal Process Outsourcing to India: So Hot Right Now!, 62 SMU L. Rev. 1889 (2009) (quoting: NirajSheth\& Nathan Koppel, With Times Tight, Even Layers Get Outsourced, Wall St. J., Nov. 26, 2008, at B1.)
} 
business in India alone, with projected revenue exploding to $\$ 4$ billion by $2015{ }^{132}$ However, U.S. firms have been cautious in the type of work outsourced as U.S. Model Rules of Professional Conduct require outsourcing attorneys to supervise the work of non-lawyer assistants to ensure competency, and MRPC Rule 5.5 prohibits the outsourcing lawyer from assisting another in the unauthorized practice of law. Moreover, with the definition of "unauthorized practice of law" varying from jurisdiction to jurisdiction, it is not surprising that most legal process outsourcing has been limited to delegation of "the more mundane but nonetheless time-intensive tasks associated with legal practice, reviewing mountains of documents for discovery rather than drafting appellate briefs." ${ }^{133}$

Because the Model Rules of Professional Conduct that appear to limit the scope of outsourced legal work, govern non-lawyer assistants and the unauthorized practice of law, a full fledged attorney licensed to practice in the relevant jurisdiction should be able to practice from within the jurisdiction, from the other side of the country while on vacation, or from, for that matter, India. Thus, in light of the Lacy and Kane Committees' failure to distinguish between facilitating eligibility of foreign-educated attorneys to practice in the U.S. and facilitating mere admission to the bar in a U.S. jurisdiction, an expansion of accreditation to foreign law schools may promote the practice of foreign attorneys flying into a U.S. jurisdiction to take the bar, and then heading back to their home jurisdiction to practice close to their loved ones. Although a very small number of jurisdictions require applicants for the bar to be U.S. citizens, ${ }^{134}$ major U.S. legal markets such as New York, California, and the District of Columbia, have no such requirements, and no U.S. jurisdiction requires applicants to obtain state residency. ${ }^{135}$ Moreover, although requirements of several jurisdictions that a licensed attorney maintain a "bona fide office" in the jurisdiction, ${ }^{136}$ have been upheld as Constitutional, ${ }^{137}$ such a requirement may be satisfied by affiliation with the bona fide office of a U.S. firm, regardless of where the firm's attorney practices. Thus, it is, if not plausible, at least conceivable that an expansion of accreditation activities to foreign law schools would not only permit foreign-educated attorneys to sit for the bar exam in the U.S., but may also extend the scope of permissible outsource legal services. That is, although legal process outsourcing is generally more cost efficient to U.S. firms, "you have

\footnotetext{
${ }^{132}$ Id. citing: Posting of MeghaPande to Legal Process Outsourcing Blog, 2009: What Lies Ahead for Indian LPO Companies?,http://legallyours.blogspot.com/2009/01/2009-what-lies-ahead-for-indian-Ipo.html (accessed on March 21, 2011).

${ }^{133}$ Anthony Lin, Legal Outsourcing to India is Growing, but Still Confronts Fundamental Issues, N.Y.L.J., Jan. 23, 2008.

134 Jurisdictions with a U.S. residency requirement include: Arkansas, Connecticut, New Hampshire, Rhode Island. Chart 1: Basic Information, Comprehensive Guide to Bar Admission Requirements, National Conference of Bar Examiners and American Bar Association Section of Legal Education and Admissions to the Bar. (2011) http://www.ncbex.org/comprehensive-guide-to-bar-admissions/

${ }^{135}$ State residency requirements have been struck down as violating the Privileges and Immunities Clause of the U.S. Constitution. It is unclear if the same would hold true for attorneys who are not U.S. citizens, let alone citizens of a U.S. State. See: New Hampshire v. Piper, 470 U.S. 274 (1985) (Practice of law is a means of livelihood protected by the Privileges and Immunities Clause.

${ }^{136}$ Jurisdictions requiring a bona fide office: District of Columbia, Minnesota, Missouri, Mississippi, New Jersey, Ohio, South Dakota, and Tennessee. As illustrated in the United State's GATS Schedule of Specific Commitments. Laurel S. Terry, Ethics Beyond the Horizon: Why Regulate the Global Practice of Law?,34 Vand. J. Transnat'I L. 989 at 1011 (2001).

${ }^{137}$ See: Tolchin v. Supreme Court of the State of New Jersey, 111 F.3d 1099 (3d Cir. 1997)
} 
to factor in the additional costs of managing service providers, and in the context of legal services you can't just take those and flow them through directly to your client." ${ }^{\prime 38}$ Firms worried about sanctions, or worse yet malpractice, may be willing to foot the bill for a recent foreign-educated law graduate to fly into the particular jurisdiction and then fly back out to work for the firm at a cheaper wage and without the hassle of supervising a non-lawyer assistant or worry over the unauthorized practice of law.

In this context, states have few options. States do have the authority to regulate licensing of lawyers to practice in its courts. But the extent of that authority is both limited by the U.S. Constitution and the lawful assertion of federal regulatory authority, especially in the context of the Treaty powers of the federal government. ${ }^{139}$ The question turns on the existence of a power by states to limit eligibility for the bar to students who have graduated from accredited law schools within the territory of the United States. That authority is not likely to survive judicial scrutiny. ${ }^{140}$

But there is substantial irony here as well. The move to accredit foreign law schools does have the potential to extend the influence of American legal culture, and to universalize the principles of the domestic legal system of the United States to places abroad. But at the same time, accreditation effectuated at the national level also reduces the power of states, the source of lawyer licensing, to assert real authority to control the licensing of lawyers. Nationalist globalization, in the form of accreditation of foreign law schools training non-U.S. citizens in the law and legal culture of the United States, then, does not merely seek to expand the reach of U.S. law "products" abroad, it also seeks to extend national standard setting power downward to states. In this sense, the program is both global and nationalist.

\section{IV: CONCLUSION.}

There is a tremendous amount of activity in the United States touching on the internationalization of legal education. But the activity points in two incompatible directions. One is internationalist in character, founded on the idea that legal education should expand to include the development of and training in law and governance systems and

\footnotetext{
138 Joshua Scott, ANALYSIS: Legal Process Outsourcing: Just Hot Air?, ALB Legal News (Dec. 18, 2008), http://asia.legalbusinessonline.com/news/breaking-news/32013/details.aspx (accessed March 22, 2011)

${ }^{139}$ Cf. Goldfarb v. Board of Examiners, 421 U.S. 773 (1975)(holding that state has substantial interest in the qualifications of those admitted to practice law within its jurisdiction and such an interest establishes broad powers to promulgate standards for licensing)

${ }^{140}$ In Matter of Tocci, 413 Mass. 542 (1992), the Massachusetts Supreme Court held that state regulations granting eligibility to a foreign-educated applicant found qualified by alternative means while denying admission to a U.S. graduate of an unaccredited law school ineligible did not violate the equal protection clause. The court reasoned that, "because the ABA does not evaluate foreign law schools for accreditation, it is reasonable to provide an alternative approval system for foreign law school graduates." Because the Tocciopinion suggested that discrimination between applicants was justified based on a lack of ABA accreditation overseas, one has to assume that if the foreign applicants at issue in Tocci had graduated from a foreign law school accredited by the ABA, the result would have been the same. That is, one can infer that states are free to discriminate based on the accreditation status of an applicant's law school, regardless of where that accredited law school is located.
} 
fields beyond those of any particular domestic legal order. The other is nationalist with global aspirations. It is founded on the idea that in global markets for law, the domestic legal systems of states compete with each other for dominance and control of law markets - that is of the construction of law systems beyond the national. As such, nationalists think in terms of globalization of the domestic legal order rather than of the internationalization of legal orders through collaborative, networked, or communal projects. One project seeks a newer framework for the construction of shared legal structures grounded in joint effort that is not dominated by the approaches of any one state; the other seeks to globalize domestic norms in the context of a framework that, having commodified law (and especially its systemic qualities), then seeks to acquire the widest market share.

Both internationalist and nationalist models of legal education draw from larger movements that have been shaping global politics and economic organization. Legal internationalism is grounded in the ideologies of supra nationalism that is tied to the creation of an international political architecture, especially that which has been influential since 1945. Nationalist legal globalization is grounded in the principles and outlook of economic globalization tied to commodification of law and completion among law system providers for dominance in markets for law studies.

Both approaches to internationalization have strong supporters in the United States. Both have been making substantial progress in terms of their development and implementation within U.S. law schools. Foreign law schools appear receptive to both. Which of the two will prevail and what the emerging consensus will be remains to be seen. For the moment, it seems that the development of law beyond the state, and the methodologies of legal education, will see both internationalization and nationalist globalization models grow better defined and more thoroughly implemented. 


\section{REFERENCES}

ABRISKETA URIARTE, J. Y CHURRUCA MUGURUZA, C. El Máster Europeo Conjunto en Acción Internacional Humanitaria: un másterbasado en competencias [Universidad de Deusto]. Congreso sobre la internacionalización de la educación superior de derecho. Toledo, Spain. 2011.

NAVEED AHMAD. Designing and Implementing a Legal English Course to Develop the Rule of Law in the Context of Transition in Pakistani Society. Ronald A. Brand and D. Wes Rist, eds.The Export of Legal Education. Fanham. Surry, UK. Ashgate 2009.

ARJONA SEBASTIÀ, C. Transnational Law as an Excuse. How Teaching Law Without the State Makes Legal Education Better. C. Menkel-Meadow \& F. Werro (eds.), Teaching Transnational Law. Ashgate (forthcoming, 2011).

JELANA ARSIC. The Socratic Method, Clinical Legal Education, and Mediation: Serving the Promotion of Rule of Law in Serbia. Ronald A. Brand and D. Wes Rist, eds. The Export of Legal Educaiton. Fanham. Surry, UK. Ashgate 2009.

CATÁ BACKER, L. Human Rights and Legal Education in the Western Hemisphere: Legal Parochialism and Hollow Universalism. 21 Penn State International Law Review 115, 151. 2002.

Internationalizing the American Law School Curriculum (in Light of the Carnegie Foundation's Report). The Internalization of Law and Legal Education 49-112 (Jan Klabbers and Mortimer Sellers, Dordrecht, The Netherlands: Springer Science + Business Media B.V., 2008) (2 lusGentium: Comparative Perspectives on Law and Justice (Mortimer Sellers series ed.).

Inter-Systemic Harmonization and Its Challenges for the Legal-State, in the Law of the Future and the Future of Law. HiiL Law of the Future Series, The Law of the Future and the Future of Law, Sam Muller, Stavros Zouridis, Laura Kistemaker and MorlyFrishman, eds., The Hague, Netherlands: TorkelOpsahi Academic Editor, 2011.

JOHN A. BARRETT, JR. International Legal Education in U.S. Law Schools: Plenty of Offerings but Too Few Students. 31 Int'l Law. 845 (1997)

BERMEJO CASTRILLO, M. Y OTERO GONZÁLEZ, P. Hacia una formación jurídica sin fronteras. El reto de la implantación de titulaciones conjuntas de dimensión internacional [Universidad Carlos III de Madrid]. Congreso sobre la internacionalización de la educación superior de derecho. Toledo, Spain. June 15, 2011.

RONALD A. BRAND AND D. WES RIST, EDS. The Export of Legal Educaiton. Fanham Surry, UK. Ashgate 2009.

CÉSPEDES ZAVALETA, A. The Impact of the U.S. Legal System on Peruvian Administrative Law. Ronald A. Brand and D. Wes Rist, eds. The Export of Legal Education. Fanham. Surry, UK. Ashgate 2009. 
D'ALEMBERTE, S. Report of the Law School Accreditation Task Force. ABA Sec. on Legal Educ. and Admissions to the Bar. 2009

F. DEL DUCA, L \& P. SCIARRA, V. Developing Cross-Border Practice Rules: Challenges and Opportunities for Legal Education. 21 Fordham Int'I L.J. 1109. 1998. J. GOEBEL, R. Professional Qualification and Educational Requirements for Law Practice in a Foreign Country: Bridging the Cultural Gap, 63. Tul. L. Rev. 443, 4471989.

Goldfarb v. Board of Examiners, 421 U.S. 7731975.

HANSON, A. Legal Process Outsourcing to India: So Hot Right Now! 62 SMU L. Rev. 1889 (2009).

HUSSAIN, V. Note, Sustaining Judicial Rescues: The Role of Outreach and CapacityBuilding Efforts in War Crimes Tribunal. 45 Va. J. Int'I L. 5472005.

JUKIER, R. Transnationalizing the Legal Curriculum: How to Teach What We Live. $56 \mathrm{~J}$. Leg. Educ. 1722006.

HONGJUKOH, H. Luncheon Address (May 17, 2006), in American Law Institute Remarks and Addresses. $83^{\text {rd }}$ Annual Meeting, Washington, D.C. pp. 65-89.

LEBEL-GRENIER, S. What is a Transnational Legal Education. 56 J. Leg.Educ. 1902006.

LIN, A. Legal Outsourcing to India is Growing, but Still Confronts Fundamental Issues. N.Y.L.J., Jan. 23, 2008

Matter of Tocci, 600 N.E.2d 577 (MA, 1992).

MCWHINNEEY, E. Codifying International Law in an Era of Clashing Civilizations and Legal Cultures: The Sisyphaen Labors of the International Law Commission. Law and Legal Culture in Comparative Perspective 222-244. Guenther Doeker-Mach and Klaus A. Ziegert, ed. Munich \& Wiesbaden: Franz Steiner Verlag, 2004.

New Hampshire v. Piper, 470 U.S. 274. 1985.

AUGUSTINE S.J. PARK. Peacebuilding, the Rule of Law and theProblem of Culture: Assimilation, Multiculturalism, Deployment. Journal of Inrevention and Statebuilding4(4): 413-432 (2011).

H. PETERSON, J. 'Rule of Law' Initiatives and the Liberal Peace: The Impact of Politicised Reform in Post-Conflict States. Disasters 34: S15-S39. 2010.

REICH, N. Recent Trends in European Legal Education: The Place of the European Law Faculties Association. 21 Penn St. Int'I L. Rev. 21. 2002.

RONALD D. ROTENDA \& JOHN S. DZIENKOWSKI. Legal Ethics: A Lawyer's Deskbook on Professional Responsibility. \& 5.3-2 n.6. 2009-2010. 
SANDBERG, H. Legal Colonialism-Americanization of Legal Education in Israel. Global Jurist: Vol. 10; Iss. 2; Art.6. 2010.

MATHEW D. SHAVER. Lifting the Veil: an Expose on the American bar Association's Arbitrary and Capricious Accreditation Process. 49 Wayne L. Rev. 1. 2003.

SHETH, N. \& KOPPEL, N. With Times Tight, Even Layers Get Outsourced, Wall St. J., Nov. 26, 2008, at B1

L. STRAUSS, P. Transsystemia-Are We Approaching a New Langdellian Moment? Is McGill Leading the Way? 56 J. Leg. Educ. 161. 2006.

WILLIAM M. SULLIVAN, ANNE COLBY, JUDITH WELCH WEGNER, LLOYD BOND and LEE S. SHULMAN. Educating Lawyers: Preparation for the Profession of Law. Carnegie Foundation. San Francisco: Jossy-Bass. 2007.

S. TERRY, L. Ethics Beyond the Horizon: Why Regulate the Global Practice of Law? 34 Vand. J. Transnat'I L. 989 at 1011. 2001.

--------. From GATS to APEC: The Impact of Trade Agreements on Legal Services, 43 Akron L. Rev. 875. 2010.

TEUBNER, G. ed. Autopoietic Law: A New Approach To Law And Society. 1988.

W. WEGNER, J. "Reframing Legal Education's Wicked Problems". 61(4) Rutgers Law Review 867-1008. 2009.

ZAMBRANA TÉVAR, N. La globalización de lasFacultades de Derecho: el Global Law Program de la Universidad de Navarra [Universidad de Navarra]. Congreso sobre la internacionalización de la educación superior de derecho. Toledo, Spain. 2011.

American Bar Association Section of Legal Education and Admissions to the Bar, Proposed Model Rule on Admission of Foreign Educated Lawyers. http://www.americanbar.org/content/dam/aba/administrative/legal education and admissionstothebar/councilreportsandresolutions/20110420modelruleandcriteria-foreignlawyers.authcheckdam.pdf (accessed 7/1/11).

American Bar Association, Report of Special Committee on Foreign Law Schools Seeking Approval Under ABA Standards, July 19, 2010. Available http://www.abajournal.com/files/kanereportinternational.pdf.

, Press Release, ABA Now, ABA Legal Education Section Delays Decision on Accrediting Foreign Law Schools, (Dec. 4, 2010) http://www.abanow.org/2010/12/abalegal-education-section-decides-to-continue-consideration-of-whether-to-accreditforeign-law-schools/

Rule of Lawlnitiative, Home, available http://apps.americanbar.org/rol/.

Section of Legal Education and Admissions to the Bar, About the Section. Available http://www.americanbar.org/groups/legal education.html. 
Comments on Accreditation of Foreign Law Programs, AmericanBar.org, http://apps.americanbar.org/legaled/accreditation/Comments on Accreditation of Foreign Schools.html (last visited Feb. 27, 2010)

Conference of Chief Justices, Resolution 8 Regarding Accreditation of Legal Education in Common Law Countries by the ABA Section on Legal Education and Admission to the Bar.

http://ccj.ncsc.dni.us/LegalEducationResolutions/resol8AccredLegalEducCommonLawC ountries.html. Feb, 2007.

Marcella David, Assoc. Dean for Int'l and Comparative Law, Univ. of lowa College of Law, e-mail to ABA Sec. of Legal Educ. and Admissions to the Bar. Sept 21, 2010. http://apps.americanbar.org/legaled/accreditation/Comments on Foreign Program Accreditation/MarcellaDavid.pdf

Irv Freeman, e-mail to Chair Durham and Members of the Council. Aug. 31, 2010. http://apps.americanbar.org/legaled/accreditation/Comments on Foreign Program Accreditation/Irv Freeman.pdf

Georgetown University Law School, Centre for Transnational Legal Studies, Website. Available at http://ctls.georgetown.edu/.

- Informational Brochure. Available http://www.google.com/url?sa=t\&source=web\&cd=2\&ved=0CCAQFjAB\&url=http\%3A \%2F\%2Fctls.georgetown.edu\%2Fdocuments\%2FCTLSLondonBrochurePT.pdf\&rct=j\&q= georgetwon\%20center\%20for\%20translational\%20legal\%20studies\&ei=ctM1To6NAn00gGFufTwDw\&usg=AFQjCNENfxUZONjAeOPSxNzkvbuiVhQofg\&cad=rja.

Jerry Hafter, Honorable Christin Durham, and Dean John O'Brien, Memorandum to Sandy D'Alemberte (10/8/09) http://apps.americanbar.org/legaled/section/ACtaskforcereport.pdf.

Paul Harris, "Hawks Depart as Clinton ushers in new era of US 'soft power'. The Guardian (UK), Jan. 11, $2009 . \quad$ Available http://www.guardian.co.uk/world/2009/jan/11/obama-white-house-clinton.

Peter Joy, Prof. of Law, Washington Univ. in St. Louis School of Law, letter to Hulett H. Askew, Consultant on Legal Educ., Sec. of Legal Educ. and Admissions to the Bar (Sept. 20, 2010) http://apps.americanbar.org/legaled/accreditation/Comments on Foreign Program Accreditation/PeterJoy.pdf.

Mary K. Kane, Report of Special Comm. on Foreign Law Schools Seeking Approval Under ABA Standards, 2009 A.B.A. Sec. of Legal Educ. and Admissions to the Bar (Kane Report). § II at 5, 6, 7.http://www.abajournal.com/files/kanereportinternational.pdf

Robert R. Kuehn, President, Clinical Legal Education Association, letter to Hulett $\mathrm{H}$. Askew, Consultant on Legal Educ., Sec. of Legal Educ. and Admissions to the Bar (Oct. 15, 2010) http://apps.americanbar.org/legaled/accreditation/Comments on Foreign Program Accreditation/CLEA.pdf. 
AishaLabi, As Universities Globalize, Consortia Take On a New Meaning, Chronicle of Higher Educaiton, Aug. 13, 2011. Available http://chronicle.com/article/AsUniversities-Globalize/128633/?sid=gn\&utm source=gn\&utm medium=en.

Honorable Elizabeth B. Lacy, Report of the Special Comm. on International Issues, 2009 A.B.A. Sec. of Legal Educ. and Admissions to the Bar (Lacy Report) http://www.abajournal.com/files/FINAL.pdf.

Carolyn Lamm, Immediate Past President, ABA, Memorandum to Judge Christine M. Durham, Chair, Sec. of Legal Educ. and Admissions to the Bar (Nov. 23, 2010)http://apps.americanbar.org/legaled/accreditation/Comments on Foreign Program Accreditation/CarolynLamm.pdf

Jeffrey Lehman, Chancellor and Founding Dean, Peking University School of Transnational Law, letter to The Council of the Sec. of Legal Educ. and Admissions to the Bar (Oct. 15, 2010) http://apps.americanbar.org/legaled/accreditation/Comments on Foreign Program Accreditation/Peking University.pdf

Brian Leiter, "National" and "Regional" Law Schools," Brian Leiter's Law School Reports, Feb. 6, 2006, available http://leiterlawschool.typepad.com/leiter/2006/02/national and re.html.

--------. Brian Leiter's Law School Reports, available
http://leiterlawschool.typepad.com/.

Michael M. Martin, Interim Dean and Distinguished Prof., Fordham Univ. School of Law, e-mail to Hulett Askew, Consultant of Legal Educ., Sec. of Legal Educ. and Admissions to Be Bar (Oct. 13, 2010) http://apps.americanbar.org/legaled/accreditation/Comments on Foreign Program Accreditation/Fordham.pdf

National Conference of Bar Examiners and American Bar Association Section of Legal Education and Admissions to the Bar: Comprehensive Guide to Bar Admission Requirements, 2011, Chart 4. http://www.americanbar.org/content/dam/aba/migrated/legaled/publications/20110 201 Comp Guide.authcheckdam.pdf (accessed 7/1/11).

Jeremy Paul, Dean, University of Connecticut School of Law, letter to Hulett Askew, Consultant on Legal Educ., Sec. of Legal Educ. and Admissions to the Bar (Oct. 15, 2010) http://apps.americanbar.org/legaled/accreditation/Comments on Foreign Program Accreditation/Jeremy Paul.pdf.

Stephen Presser, Raoul Berger Professor of Legal History, Northwestern University School of Law. Quoted in: Karen Sloan, ABA Proposes Big Changes for LL.M.S, Law.com (5/24/2011) http://www.law.com/jsp/law/LawArticleFriendly.jsp?id=1202494952850 (accessed 7/1/11). 
Martin Schuster, "The EU's Rule of Law Initiative for Central Asia: From Initiative to More Substance?, EUCAM Policy Brief No. 18, June 2011. Available http://www.google.com/url?sa=t\&source=web\&cd=5\&ved=0CDgQFjAE\&url=http\%3A \%2F\%2Ffride.org\%2Fdescarga\%2FPB EUCAM 18.pdf\&rct=j\&q=effects\%20rule\%20of\% 20law\%20initiatives\&ei=A29OTrLqJ5ScgQenvL2QBw\&usg=AFQjCNGdv7ZuTITkfCBUilQbKSqS2vN5w\&cad=rja.

Joshua Scott, ANALYSIS: Legal Process Outsourcing: Just Hot Air?, ALB Legal News (Dec. 18, 2008), http://asia.legalbusinessonline.com/news/breakingnews/32013/details.aspx (accessed March 22, 2011).

State of New York Court of Appeals, Notice to the Bar, Study of Law in Foreign Country; Required Legal Education, State of New York Court of Appeals, http://www.courts.state.ny.us/CTAPPS/news/nottobar/StudyofLawForeignCountry.pdf (accessed 7/1/11).

"The ABA sounds off on foreign-trained attorneys," The Posse List, May 24, 2011, available http://www.theposselist.com/2011/05/24/the-aba-sounds-off-on-foreigntrained-attorneys/.

The Global 100 2010: The Worlds Highest Grossing Law Firms, American Lawyer, http://www.law.com/isp/tal/PubArticleTAL.jsp?id=1202472338838 (Accessed 7/1/11).

Tolchin v. Supreme Court of the State of New Jersey, 111 F.3d 1099 (3d Cir. 1997).

U.S. News \& World Report (U.S. News \& World Report, Guide to Law Schools, Rakings, available at

http://gradschols.usnews.rankingsandreviews.com/usnews/edu/grad/rankings/law/la windex brief.php (accessed Aug. 27, 2007) 